\title{
Changes in nutritional quality and nutrient limitation regimes of phytoplankton in response to declining $\mathrm{N}$ deposition in mountain lakes
}

\author{
Ann-Kristin Bergström ${ }^{1}$ (D - Anders Jonsson ${ }^{1}$ - Peter D. F. Isles ${ }^{2}$ - Irena F. Creed ${ }^{3}$. Danny C. P. Lau ${ }^{1,4}$
}

Received: 14 March 2019 / Accepted: 9 January 2020 / Published online: 24 February 2020

(c) The Author(s) 2020

\begin{abstract}
Phytoplankton play a key role in supporting aquatic food webs. However, the effects of ongoing large-scale changes in the concentrations and stoichiometry of important biological compounds [dissolved inorganic N (DIN), total phosphorus (TP), dissolved organic carbon (DOC) and DIN:TP] on the development and nutritional quality of phytoplankton for higher trophic levels are unclear. We conducted lake studies and in situ bioassay experiments in two Swedish mountain regions [Abisko (north) and Jämtland (south)] with different $\mathrm{N}$ deposition and where lakes in each region were distributed along a similar gradient in lake DOC $\left(2-7 \mathrm{mg} \mathrm{L}^{-1}\right)$ to assess whether differences in nutrients, DOC and DIN:TP induced differences in phytoplankton quantity [chlorophyll $a(\mathrm{Chl}-a)$ and seston carbon $(\mathrm{C})$ ] and quality [seston C:N:P stoichiometry and fatty acid (FA) composition]. Using long-term monitoring data from lakes in these two mountain regions, we found declining longterm trends in $\mathrm{N}$ deposition and lake DIN and total TP concentrations, but not in lake DIN:TP. Lakes in Abisko received lower N deposition and had lower DIN:TP than those in Jämtland. Phytoplankton was N- to NP-limited in Abisko lakes but NP dual-limited in Jämtland lakes. The $\mathrm{N}$ fertilization effects induced by higher DIN:TP were weak on phytoplankton quantity but strong on phytoplankton quality. The phytoplankton had lower eicosapentaenoic acid (EPA) content and higher $\mathrm{P}$ content (lower seston C:P) in Abisko compared to in Jämtland. In addition, the quality of the DOC (as indicated by its aromaticity and SUVA) influenced not only the light conditions and the seston C:P ratios, but also the FA composition. We found higher bacteria FA concentrations in seston in Abisko than in Jämtland, despite lower amounts of FA of terrestrial origin in Abisko. Our findings suggest that declining $\mathrm{N}$ deposition and enhanced colored terrestrial $\mathrm{C}$ loadings leads to lower nutritional quality of basal resources for higher consumers in mountain lakes.
\end{abstract}

Keywords Phytoplankton $\cdot$ Nutritional quality $\cdot$ Fatty acids $\cdot$ Mountain lakes $\cdot$ Sweden

Electronic supplementary material The online version of this article (https://doi.org/10.1007/s00027-020-0697-1) contains supplementary material, which is available to authorized users.

Ann-Kristin Bergström

ann-kristin.bergstrom@umu.se

1 Department of Ecology and Environmental Science, Umeå University, Umeå, Sweden

2 Department of Aquatic Ecology, Swiss Federal Institute of Aquatic Science and Technology, Dübendorf, Switzerland

3 School of Environment and Sustainability, University of Saskatchewan, Saskatoon, SK, Canada

4 Department of Ecology and Environmental Science, Climate Impacts Research Centre, Umeå University, Abisko, Sweden

\section{Introduction}

Mountain lakes serve as sentinels of climate change (Williamson et al. 2008, 2016) and provide important ecosystems services for people in the north (e.g., drinking water, fisheries, recreation and tourism) (Chapin et al. 2004). Being nutrient poor, these lake ecosystems may respond strongly to even small environmental changes that affect the nutrient limitation regimes of phytoplankton. Recent studies from eastern North America and Scandanavia indicate that nutrient concentrations [dissolved inorganic nitrogen (DIN) and total phosphorus (TP)] in northern nutrient poor lakes are declining (Eimers et al. 2009; Canham et al. 2012; Huser et al. 2018; Isles et al. 2018), while concentrations of dissolved organic carbon (DOC) are increasing (Monteith et al. 2007; de Wit et al. 2016; Kritzberg 2017). The effect 
of declining trends in nutrient concentrations is a general decline in DIN:TP ratios, implying that phytoplankton $\mathrm{N}$ limitation is becoming more widespread in nutrient poor lakes (Isles et al. 2018). However, our knowledge is currently limited as to the extent that declining trends in nutrient concentrations and DIN:TP ratios in the face of increasing DOC trends affect nutrient limitation regimes and phytoplankton quantity and quality [i.e., carbon:nitrogen:phosphorus (C:N:P) stoichiometry and fatty acid (FA) composition] in mountain lakes. At risk are trophic transfer efficiencies in pelagic food webs and thus productivity.

Declines in lake DIN concentrations are associated with declining inputs of reactive $\mathrm{N}$ from the atmosphere (Simpson et al. 2014; Isles et al. 2018), whereas declines in lake TP concentrations are associated with climate change and recovery from acidification effects on catchment processes (Huser et al. 2018; Isles et al. 2018). Earlier studies have shown that elevated $\mathrm{N}$ deposition raised lake water $\mathrm{N}: \mathrm{P}$ stoichiometry in many northern oligotrophic lakes, which in turn shifted phytoplankton from N- to P-limited conditions (Bergström et al. 2005; Elser et al. 2009a), increased biomass (Bergström and Jansson 2006) and C:P and N:P ratios in phytoplankton (Elser et al. 2009b, 2010). This $\mathrm{N}$ fertilization effect may have benefitted higher trophic levels by raising phytoplankton quantities (Persson et al. 2007), or may have impaired higher trophic levels since P-limited phytoplankton with high C:P have poor nutritional quality (Sterner and Elser 2002; Hessen 2013). Recent declines in $\mathrm{N}$ deposition in northern oligotrophic lakes and associated declines in concentrations of DIN, TP and DIN:TP ratios may therefore lead to reduced phytoplankton quantities and a shift "back" to original states in phytoplankton nutrient limitation regimes (i.e., from $\mathrm{P}$ - to $\mathrm{N}$-limitation), with higher nutritional quality (i.e., lower $\mathrm{C}: \mathrm{P}$ ). This change may be especially pronounced in clear-water mountain lakes with sparsely vegetated catchments with low capacity of retaining DIN from deposition and with low input of $\mathrm{P}$ from soils (Hessen et al. 2013).

Environmental changes that affect lake nutrient limitation regimes and phytoplankton quantity may also affect FA in phytoplankton, especially of polyunsaturated fatty acids (PUFA). PUFA, which are produced de novo by phytoplankton [e.g. eicosapentaenoic acid (EPA, 20:5 docosahexaenoic acid (DHA, 22:6w3)] (Napolitano 1999; Müller-Navarra 2008), are essential biochemical food components for growth and reproduction in zooplankton (Müller-Navarra 2008). In addition to phytoplankton C:N:P stochiometry, phytoplankton PUFA content is also a major determinant of energy transfer efficiency in lake food webs (Persson et al. 2007; Müller-Navarra et al. 2000). High N concentration in clear-water lakes has also been shown to promote high biomass of phytoplankton with high nutritional quality in terms of its FA composition, such as the edible phytoplankton (Rhodomonas and cryptophytes) (Gutseit et al. 2007) that are rich in EPA and DHA (Taipale et al. 2013). Laboratory experiments have shown that the nutrient limitation regime affects the biochemical composition of phytoplankton. P-limited conditions have been shown to reduce EPA concentration (Müller-Navarra 1995; Gulati and DeMott 1997; Sundbom and Vrede 1997), whereas N-limited conditions reduce amino acid content (Ahlgren and Hyenstrand 2003). However, to our knowledge, no in-lake studies have assessed nutrient limitation regimes in phytoplankton in parallel with assessing their mineral $(\mathrm{C}: \mathrm{P}, \mathrm{N}: \mathrm{P})$ and biochemical (FA) composition.

Changes in terrestrial inputs of colored dissolved organic carbon (DOC) may also affect phytoplankton quantity and quality. Although terrestrial loadings of colored DOC have been increasing in many lakes in the north (i.e., referred to as lake browning) (Monteith et al. 2007; de Wit et al. 2016; Finstad et al. 2006; Kritzberg 2017), this does not seem to be the case for some northern mountain lakes (de Wit et al. 2016; Isles et al. 2018). Terrestrial colored DOC loadings may affect nutrient limitation regimes in phytoplankton by co-transporting nutrients (Jones 1992; Kortelainen et al. 2006) and by reducing light climates in lakes (Carpenter et al. 1998; Deininger et al. 2017). This tradeoff between light and nutrient availability promotes unimodal distributions of phytoplankton biomass with increasing lake DOC, where the position and magnitude of the biomass peak are determined by light availability and DOC:nutrient stoichiometry, respectively (Kelly et al. 2018; Bergström and Karlsson 2019). The mineral content in phytoplankton is also affected by the declining light per nutrient availability that follows with increased lake DOC (i.e., the light:nutrient hypothesis; Sterner et al. 1997), promoting high C:P in phytoplankton in clear-water lakes and vice versa in humic and dark lakes. The inverse relationship between DOC quantity and $\mathrm{C}: \mathrm{P}$ ratios in phytoplankon may be further modified by DOC quality (its aromaticity) through its effects on the light climate (Sterner et al. 1997; Kelly et al. 2018). Since terrestrial DOC serves as an energy and carbon source for bacteria (Tranvik et al. 1988), enhancing lake bacterial biomass and production (Hessen 1985; Jansson et al. 2001, 2003), the amounts of bacterial FA (BAFA) in seston are expected to increase with colored DOC concentration in lakes.

In this study we explored the effects of nutrient limitation on phytoplankton quality and quantity by performing seasonal lake studies in two mountain regions, one in Abisko (north; 8 lakes studied in 2016) and the other in Jämtland (south; 7 lakes studied in 2017) in northern Sweden. These regions differ in climate and $\mathrm{N}$ deposition, but lakes in each region were distributed along a similar range in lake DOC concentration $\left(2-7 \mathrm{mg} \mathrm{L}^{-1}\right)$. We assessed phytoplankton nutrient limitation regimes in each region by performing in situ bioassay experiments with $\mathrm{N}, \mathrm{P}$ or $\mathrm{N}+\mathrm{P}(\mathrm{NP})$ 
additions. We tested whether differences in nutrient limitation were linked to $\mathrm{N}$ deposition and lake water $\mathrm{N}: \mathrm{P}$ stoichiometry, and induced differences in phytoplankton quantity (in terms of Chl- $a$ and seston C) and quality (in terms of FA and seston C:P, N:P ratios). We also used long-term monitoring data for $\mathrm{N}$ deposition and nutrient concentrations from four mountain lakes situated in the same regions as our study lakes to assess long-term trends (from 1997 to 2017) in $\mathrm{N}$ deposition, lake DIN and TP concentrations, and DIN:TP ratios that might have promoted shifts in phytoplankton nutrient limitation regimes. We hypothesize that in these mountain lakes, $\mathrm{N}$ deposition (affecting nutrient limitation regime), in conjunction with DOC (affecting light climate), cause variation in phytoplankton nutrient limitation and in nutritional quantity and quality of food for zooplankton. Our predictions were that:

1. $\mathrm{N}$ deposition and lake DIN:TP ratios are declining in both mountain regions.

2. Phytoplankton biomass increase with $\mathrm{N}$ addition in mountain regions with lower $\mathrm{N}$ deposition and DIN:TP ratios [Abisko (north)] and with $\mathrm{P}$ addition in mountain regions with higher $\mathrm{N}$ deposition and DIN:TP ratios [Jämtland (south)].

3. Phytoplankton quantity (Chl- $a$ and seston C) is higher in mountain lakes with higher $\mathrm{N}$ deposition and higher DIN:TP [Jämtland (south)]. However, phytoplankton quality is variable. Phytoplankton are of higher quality in terms of higher PUFA contents in mountain lakes with higher DIN:TP [Jämtland (south)], but are of lower quality in terms of higher $\mathrm{C}: \mathrm{P}$ ratios in P-limited regions [Jämtland (south)] compared to N-limited regions [Abisko (north)].

4. The DIN:TP ratios are higher in mountain regions with higher $\mathrm{N}$ deposition [Jämtland (south)] and in lakes with low DOC.

5. Increasing DOC has a dual influence on overall phytoplankton quality; the influence is positive in terms of decreasing seston $\mathrm{C}: \mathrm{P}$ and negative in terms of increasing seston BAFA and FA content indicative of terrestrial plants detritus. These opposing trends are similar in Abisko (north) and Jämtland (south) since lakes in both regions are distributed along a similar DOC gradient.

\section{Material and methods}

\section{Site description}

A gradient of climate and $\mathrm{N}$ deposition exists across two subarctic mountain regions in northern Sweden [Abisko (North) and Jämtland (South)]. A total of 15 lakes (eight in Abisko, seven in Jämtland) were selected and sampled in these regions (Fig. 1; Supplementary information Table S1). All lakes are headwater lakes situated at altitudes from 350 to $622 \mathrm{~m}$ above sea level (m.a.s.l.) with no or minimal development in their catchments. Within each region, lakes along a similar gradient in DOC concentration $\left(2-7 \mathrm{mg} \mathrm{L}^{-1}\right)$ were selected to test for the effects of DOC on nutrient stoichiometry both within and between mountain regions. Lakes were sampled three times during the year (Abisko in 2016; Jämtland in 2017), once early in the growing season soon after the onset of stratification, once during the middle of summer, and once in the autumn before circulation. Sampling dates differed between the mountain regions to account for differences in ice-out, stratification, and circulation dates: Abisko was sampled on 14-19 June (early), 18-20 July (mid), and 23-28 August (late); and Jämtland was sampled on 13-18 June (early), 25-30 July (mid), and 5-10 September (late). Mean annual air temperature and mean annual precipitation were -2 to $0{ }^{\circ} \mathrm{C}$ and $600 \mathrm{~mm}$ respectively in Abisko (2016) and $1-2{ }^{\circ} \mathrm{C}$ and $700-1000 \mathrm{~mm}$, respectively in Jämtland (2017) (https://www.smhi.se).

\section{Weather, nitrogen deposition and long-term lake monitoring data}

Annual $\mathrm{N}$ deposition data (total wet + dry deposition) for $\mathrm{NO}_{3}{ }^{-}$and $\mathrm{NH}_{4}{ }^{+}$from 1997 to 2017 were obtained from the Swedish Meteorological and Hydrological Institute (SMHI; https://www.smhi.se/klimatdata/miljo/atmosfarskemi) for each of the study lakes and then averaged across sites to get annual $\mathrm{N}$ deposition estimates for each mountain region. Long-term monitoring data for DIN (sum of $\mathrm{NO}_{3}{ }^{-}$and $\mathrm{NH}_{4}{ }^{+}$) and total P (TP) concentrations were obtained for four lakes (two lakes per mountain region) located approximately 10 and $15 \mathrm{~km}$ (Abisko) and 5 and $70 \mathrm{~km}$ (Jämtland) from our sampling sites. The selected lakes were in Abisko: Abiskojaure (lake area $2.82 \mathrm{~km}^{2} ; 486$ m.a.s.l.); Latnajaure (lake area $0.73 \mathrm{~km}^{2}$; 976 m.a.s.l.) and in Jämtland: Krutejaure (lake area $0.33 \mathrm{~km}^{2} ; 819$ m.a.s.l.) and Stor-Björsjön (lake area $0.45 \mathrm{~km}^{2} ; 565$ m.a.s.l.). We used data collected from these lakes by the Swedish Long-Term-Monitoring program, including multiple samples from the epilimnion ( $\leq 2 \mathrm{~m}$ ) in each year from 1997 to 2017 (https://miljodata. slu.se/mvm/). We standardized the data by using Z scores to compare relative trends in $\mathrm{N}$ deposition and lake nutrient concentrations; for nutrient, $\mathrm{N}$ in year $\mathrm{i}$, the $\mathrm{Z}$ score was calculated as $\left(\mathrm{N}_{\mathrm{i}}-\right.$ mean $\left.(\mathrm{N})\right)$ /standard deviation $(\mathrm{N})$, and the mean Z-score for each nutrient was then calculated for the two lakes selected for each region (cf. Isles et al. 2018).

\section{Lake and catchment characteristics}

Lake and catchment morphometric characteristics were extracted from publicly available spatial datasets using 

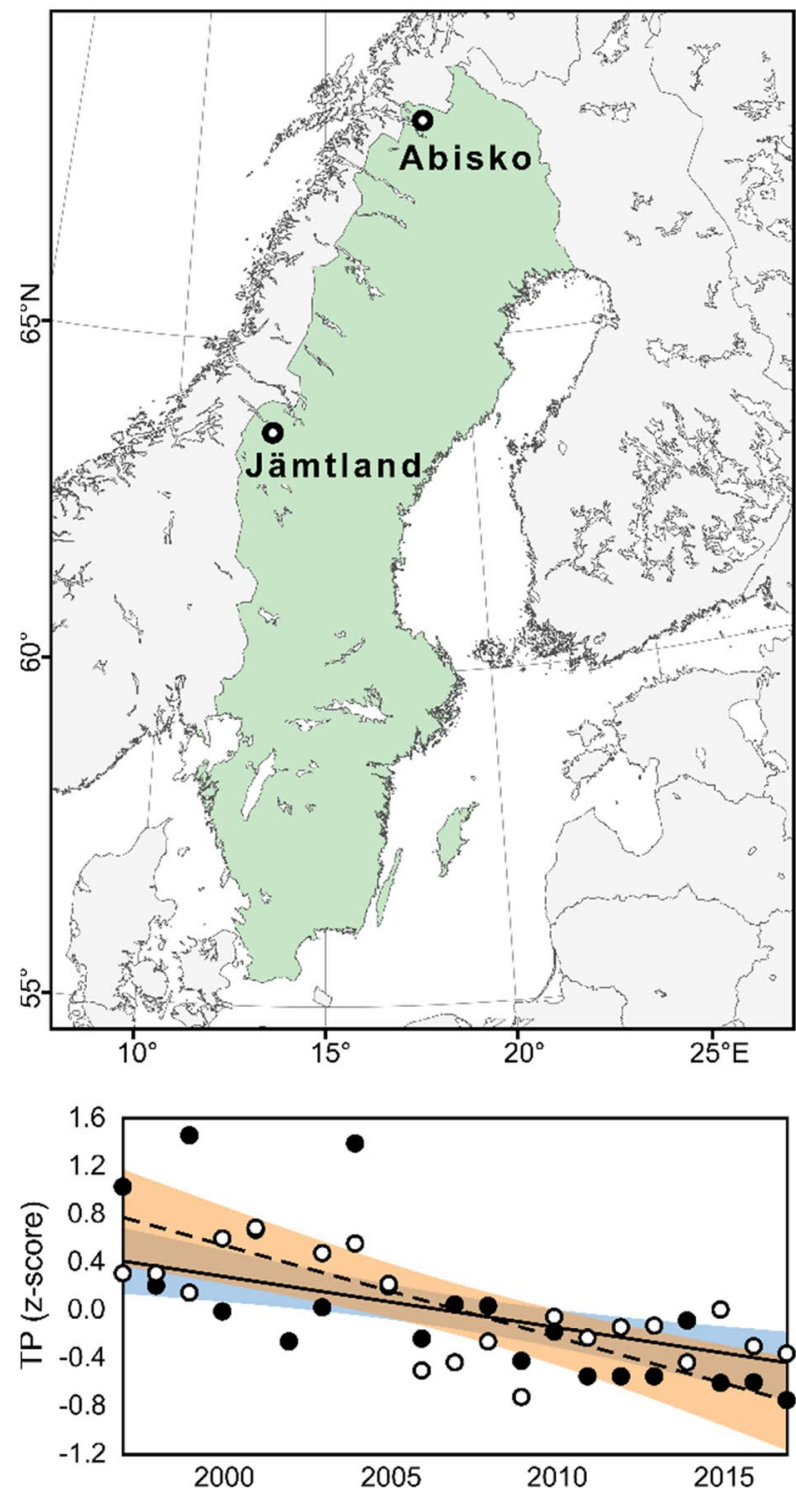

Fig. 1 The location of the two study sites (Jämtland and Abisko), and long term trends in atmospheric DIN deposition $\left(\mathrm{kg} \mathrm{ha}^{-1} \mathrm{year}^{-1}\right)$, and dissolved inorganic nitrogen (DIN), total phosphorus (TP) concen-

Whitebox (Lindsay 2016). Lake polygons were taken from the Lantmäteriet vattenytor layer (https://www.lantmateri et.se/sv/Kartor-och-geografisk-information/). Wetland polygons were taken from the Lantmäteriet myr layer. Catchment boundaries were delineated from the 2-m GSD-Höjddata grid $2+$ (source: https://www.lantmateriet.se/sv/Kartor-ochgeografisk-information/geodataprodukter/produktlista/hojdd ata-grid-2/) using the watershed tool in Whitebox. The DEM was hydrologically conditioned before catchment boundary delineation using a depression breaching algorithm. The 25 m resolution Naturvårdsverket Svenska Marktäckedata (SMD) land-cover map (sources: https://gpt.vic-metria.nu/ data/marktackedata/Vektor/Norrbotten.zip; https://gpt. regression line

Abisko
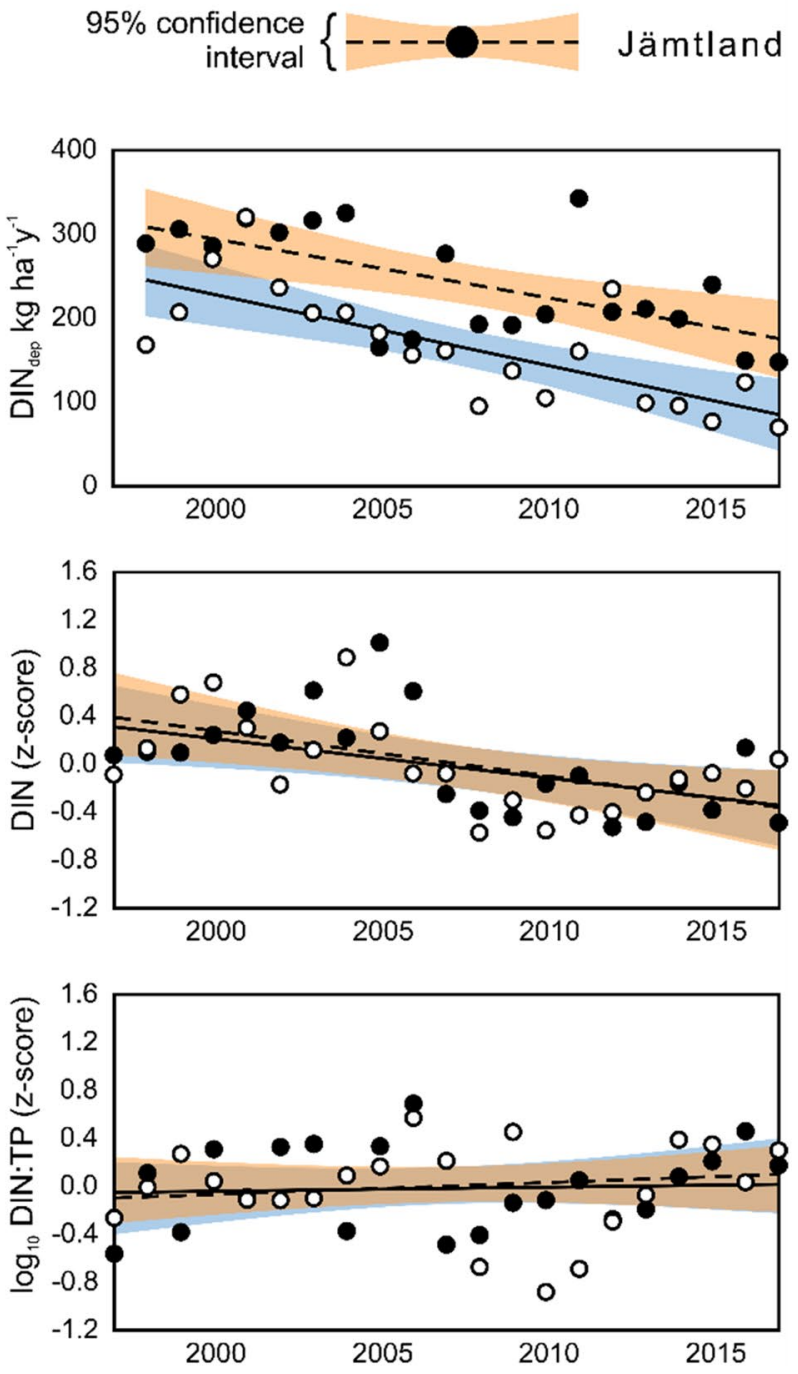

trations, and $\log _{10}$ (DIN:TP ratios) from four trend lakes (two in each region) (expressed as Z-scores)

vic-metria.nu/data/marktackedata/Vektor/Vasterbotten.zip; https://gpt.vic-metria.nu/data/marktackedata/Vektor/Jämtland.zip) was used to determine forest and agricultural cover. Drainage ratio was calculated as the ratio of catchment area to lake area.

\section{Field sampling, nutrients and fatty acid analyses}

Temperature profiles were taken at $0.5 \mathrm{~m}$ increments throughout the water column using an YSI Pro-DO sensor. Light, i.e., photosynthetically active radiation (PAR), measurements were taken at $0.5 \mathrm{~m}$ increments using a LiCOR Li-250 spherical quantum sensor. The vertical 
light extinction coefficient $\left(\mathrm{k}_{\mathrm{d}}\right)$ was calculated as the slope of the linear regression of the natural logarithm of PAR versus depth. Lake water was sampled from $1 \mathrm{~m}$ depth in Abisko where lakes were mostly not stratified over summer, and at $0.5 \mathrm{~m}$ depth in Jämtland where lakes were stratified over summer. Water samples for ammonium $\left(\mathrm{NH}_{4}{ }^{+}\right)$, nitrate/nitrite (hereafter referred to as nitrate, $\mathrm{NO}_{3}{ }^{-}$), DOC, total dissolved $\mathrm{N}$ (TDN), and absorbance were filtered through $0.45 \mu \mathrm{m}$ PES filters within $6 \mathrm{~h}$ of collection. DIN was calculated as the sum of $\mathrm{NH}_{4}{ }^{+}$and $\mathrm{NO}_{3}{ }^{-}$. DIN:TP ratios are expressed in molar ratios. All N and $\mathrm{P}$ analytes were frozen until analysis; samples for TP analysis were frozen unfiltered. DOC samples were acidified before storage (100 $\mu \mathrm{L} 1.2 \mathrm{M} \mathrm{HCl} 10 \mathrm{~mL}^{-1}$ sample). Samples collected for Chl- $a$ were kept in dark for 2-3 h until filtration (cf. below). Seston samples for analyses of seston $\mathrm{C}, \mathrm{N}$ and $\mathrm{P}$, as well as fatty-acid (FA) concentrations and compositions, were collected by prescreening lake water through a $50 \mu \mathrm{m}$ net in the field to remove large zooplankton and detritus. Seston samples were then filtered using $120-420 \mathrm{~mL}$ prescreened lake water onto precombusted $\left(550{ }^{\circ} \mathrm{C}, 3 \mathrm{~h}\right) 0.7 \mu \mathrm{m}$ glass-fiber filters that had been acid-washed $(1.2 \mathrm{M} \mathrm{HCl})$ and rinsed with MilliQwater. The volume of lake water was determined by the amount of water that could pass through the filter. Seston filters for $\mathrm{C}: \mathrm{N}: \mathrm{P}$ analyses were oven-dried at $50{ }^{\circ} \mathrm{C}$, and for FA analyses freeze-dried, and then stored at $-20{ }^{\circ} \mathrm{C}$ until further analyses of $\mathrm{C}, \mathrm{N}$, and $\mathrm{P}$ and FA.

TDN and DOC were measured on an IL-550 TOC/TN analyzer (Lange). $\mathrm{NH}_{4}{ }^{+}$and $\mathrm{NO}_{3}{ }^{-}$were measured on the flow-injection analyzer according to ISO 11732:2005, rev. 5 and ISO 13395-1996, rev. 2, respectively. Seston C and $\mathrm{N}$ were measured on a Flash EA 2000 elemental analyzer (Thermo Fisher Scientific). Total P and seston P were measured as soluble reactive phosphate using a FIA-star 5000 flow injection analyzer (FOSS) according to ISO 15681-1, rev. 4, following an acid peroxide sulfate digestion in an autoclave $\left(120^{\circ} \mathrm{C}\right)$ for $1 \mathrm{~h}$. Seston C:P and N:P ratios are expressed in molar ratios. Absorbance was measured at 250, 365 and $440 \mathrm{~nm}$ using a JASCO V-560 spectrophotometer. Carbon-specific ultraviolet absorption (SUVA), an indicator of DOC source and composition with higher SUVA corresponding to higher aromaticity (Weishaar et al. 2003), was calculated as absorbance at $250 \mathrm{~nm}$ divided by the DOC concentration. For Chl- $a$ analysis, $100 \mathrm{~mL}$ lake water was gently filtered onto $0.7 \mu \mathrm{m}$ GF/F filters using a suction pump at pressure $<5 \mathrm{~mm} \mathrm{Hg}$ to avoid cell lysis. Samples were immediately wrapped in foil and stored frozen until analysis. Chl- $a$ was extracted in $95 \% \mathrm{EtOH}$ for $24 \mathrm{~h}$, agitating several times. Chl- $a$ was then measured on a LS-55 luminescence spectrophotometer with excitation and emission wavelengths set to 433 and $673 \mathrm{~nm}$, respectively. For more detailed analytical procedures see Bergström et al.
(2013, 2015). Proportion of phytoplankton in seston C was estimated by using a conversion factor of $50 \mu \mathrm{g} \mathrm{C}$ per $\mu \mathrm{g}$ Chl- $a$ (Ahlgren 1983).

Seston FA was analyzed using a modified method based on Lau et al. (2012) and Grieve and Lau (2018). Two freezedried seston filters from each lake and sampling campaign

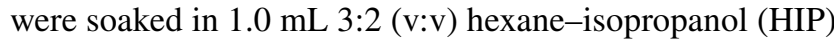
solution in a micro-centrifuge tube $(1.5 \mathrm{~mL}$ volume $)$ and kept at $4{ }^{\circ} \mathrm{C}$ in the dark for at least $16 \mathrm{~h}$ to extract the seston FA. The filters were removed. The solution was dried in an evaporator at room temperature and 0 bar for $2 \mathrm{~h}$ (miVac Quattro Concentrator, Genevac Ltd, Ipswich, England), redissolved in $400 \mathrm{~mL}$ HIP, added with $20 \mu \mathrm{L}$ internal standard deuterium-labelled pentadecanoic acid (120 ng $\mu \mathrm{L}^{-1}$; $\mathrm{C} / \mathrm{D} / \mathrm{N}$ Isotopes Inc., Essex, United Kingdom) and $111 \mu \mathrm{L}$ $6.67 \% \mathrm{Na}_{2} \mathrm{SO}_{4}$, and vortexed. The solution was kept at $4{ }^{\circ} \mathrm{C}$ in the dark for $30 \mathrm{~min}$ and then centrifuged at $18,845 \times \mathrm{g}$ for 5 min to separate the organic and aqueous phases. $150 \mu \mathrm{L}$ supernatant was transferred to a glass vial $(2.0 \mathrm{~mL}$ volume with a $300 \mu \mathrm{L}$ insert) and dried in the evaporator at room temperature and 0 bar for $2 \mathrm{~h}$.

The FA extract was dissolved in $50 \mu \mathrm{L}$ hexane plus $70 \mu \mathrm{L}$ internal standard deuterium-labelled methyl heptadecanoate (8.57 ng $\mu \mathrm{L}^{-1}$; Sigma-Aldrich Sweden AB, Stockholm, Sweden) and vortexed. $60 \mu \mathrm{L}$ of the solution was transferred to a new glass vial, added with $200 \mu \mathrm{L}$ of 1:17:83 (v:v:v) tri methylsilyldiazomethane:isopropanol:dichlormethane and vortexed. The vial was then uncapped to let the methylation proceed for about $16 \mathrm{~h}$ and the solution dry at room temperature. The resultant FA methyl esters were dissolved in $60 \mu \mathrm{L}$ heptane containing internal standards tridecane and octacosane (10 ng $\mu \mathrm{L}^{-1}$ each) and vortexed. Concentrations of FA methyl esters were quantified using a gas chromatography-mass spectrometry (7890A GC, Agilent Technologies, CA, United States; Pegasus ${ }^{\circledR}$ High Throughput TOF-MS, MI, United States) with a DB-5 capillary column (length $30 \mathrm{~m}$, internal diameter $250 \mu \mathrm{m}$, film thickness $0.25 \mu \mathrm{m}$; Agilent Technologies). The Supelco 37 Component FAME Mix (Sigma-Aldrich Sweden AB, Stockholm, Sweden) and Bacterial Acid Methyl Ester BAME Mix (Sigma-Aldrich Sweden AB) were used to identify individual FA. Splitless injection of $1 \mu \mathrm{L}$ was used for each sample. Content of individual FA in the samples were reported as $\mathrm{mg} \mathrm{FA} \mathrm{g}^{-1}$ seston C.

The identified FA were classified into four main categories, i.e., saturated FA (SAFA), monounsaturated FA (MUFA), bacteria-specific FA (BAFA) and polyunsaturated FA (PUFA) (Table 1). We focused on $\omega 3$ and $\omega 6$ PUFAs such as arachidonic (ARA), eicosapentaenoic acid (EPA) and docosahexaenoic acid (DHA) which are essential for animal physiology. These PUFA can be synthesized de novo by and are abundant in algae, but lacking in bacteria and terrestrial organic matter (Napolitano 1999). Long-chain SAFA (LongSAFA; with $\geq 20 \mathrm{C}$ ) are lacking in algae or bacteria 


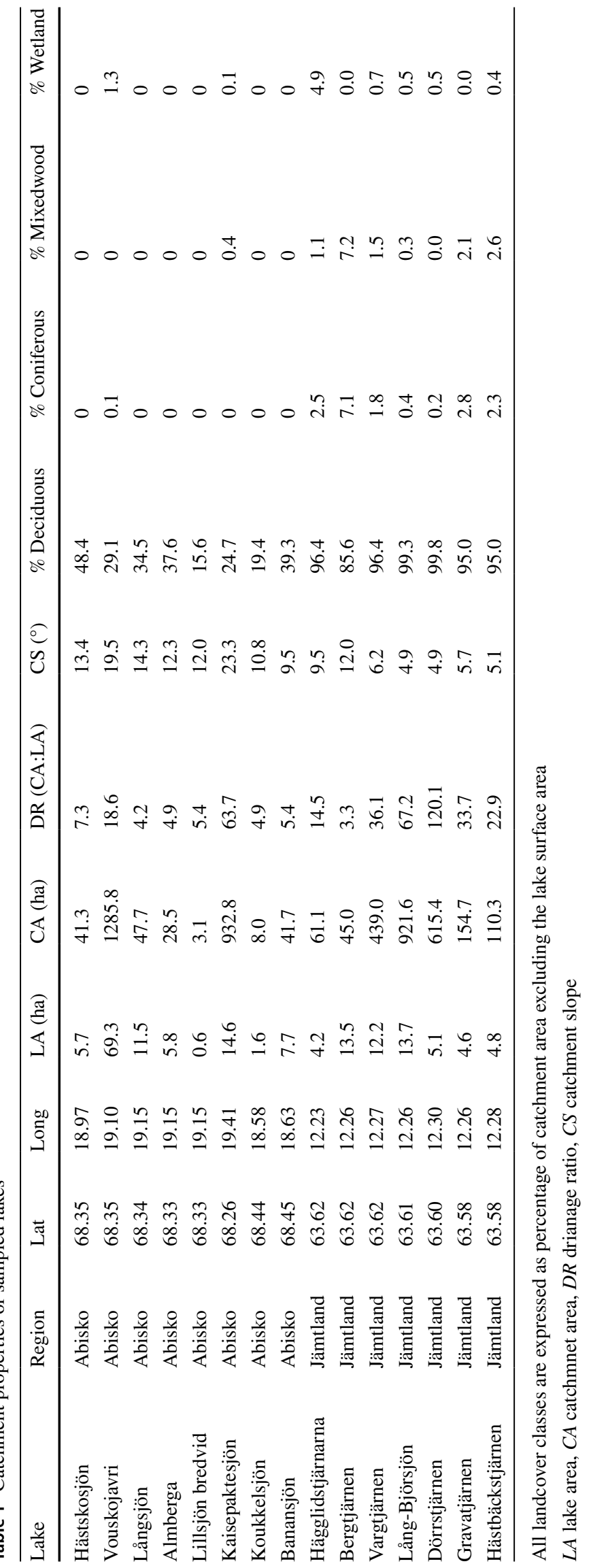


but present in terrestrial organic matter (Napolitano 1999). Short-chain SAFA (ShortSAFA; with $<20$ C) and MUFA are generally present in algae, bacteria and terrestrial organic matter. We used the $\omega 3: \omega 6$ FA ratio to indicate the relative availability of autochthonous and allochthonous resources in seston. Higher $\omega 3: \omega 6$ FA ratios occur in consumers with greater utilization of algae than terrestrial resources (Lau et al. 2013; 2014; Taipale et al. 2015) and in pelagic consumers than in littoral benthic consumers (Lau et al. 2012; 2014).

\section{Nutrient limitation assays}

Nutrient addition experiments were performed in each lake on each sampling occasion. Clear polyethylene bottles $(500 \mathrm{~mL})$ were filled with pre-filtered $(50 \mu \mathrm{m})$ epilimnetic lake water to remove large zooplankton and avoid grazing during incubations. PAR inside the polyethylene bottles was $88 \%$ of that outside the bottle. The bottles were suspended in each lake at depths corresponding to $1 / 2$ surface PAR to avoid light limitation effects but preserve in-situ epilimnetic temperature conditions. Nutrients were added, $\mathrm{N}$ as $\mathrm{NH}_{4} \mathrm{NO}_{3}$ and $\mathrm{P}$ as $\mathrm{KH}_{2} \mathrm{PO}_{4}$, to increase bottle concentrations by $100 \mu \mathrm{g} \mathrm{L}{ }^{-1} \mathrm{DIN}$ and $10 \mu \mathrm{g} \mathrm{L}^{-1} \mathrm{PO}_{4}^{3-}$. Four replicate incubations were conducted for each lake control, N, P and NP treatments. Bottles were incubated for $72 \mathrm{~h}$ and kept in the dark (2-3 h) until filtration and analysis for Chl- $a$. Chl$a$ concentrations for each treatment were averaged across replicates, and $\log _{10}$ response ratios (LRR) to $\mathrm{N}, \mathrm{P}$ or $\mathrm{NP}$ additions (LRR_N, LRR_P, LRR_NP) were calculated and averaged for each nutrient treatment relative to the control. The different types of nutrient limitation were defined as follows: N-limitation, a significantly greater response in Chl- $a$ compared to the control after $\mathrm{N}$-addition; P-limitation, a significantly greater response in Chl- $a$ compared to the control after P-addition; Dual limitation by $\mathrm{N}$ and $\mathrm{P}$, a significantly higher response in Chl- $a$ relative to controls by both $\mathrm{N}$ - and $\mathrm{P}$-additions alone; and, finally, co-limitation by $\mathrm{N}$ and $\mathrm{P}$, a significant increase in Chl- $a$ compared to the control in the $\mathrm{NP}$ treatment but no response in Chl- $a$ to $\mathrm{N}$ or $\mathrm{P}$ alone treatments (Jansson et al. 2006).

\section{Statistical analyses}

For all parameters and tests, we calculated seasonal averages for the individual lakes, and then used the seasonal averages for comparisons within and between regions. Lake water DIN:TP, Chl- $a$, seston stoichiometry (C:P, N:P), response ratios and FA data were $\log _{10}$-transformed for normal-distribution approximation and/or variance homoscedasticity. Linear regressions were used to determine if there were temporal trends in $\mathrm{N}$ deposition, and in lake DIN, TP and
DIN:TP (Z-standardized; i.e., the LTM data) (for prediction 1).

Chl- $a$, percentage phytoplankton $\mathrm{C}$ per seston $\mathrm{C}$ (\% Chl), Chl-a:TP, seston C and stoichiometry, and FA were compared between mountain regions using t-tests (or Mann-Whitney tests for non-normally distributed data) (for prediction 3). Within each mountain region, we further compared the $\log _{10}$-transformed response ratios (i.e., LRR_N, LRR_P, LRR_NP) with one-way ANOVA and post hoc Tukey tests to determine if phytoplankton were limited by $\mathrm{N}$ or $\mathrm{P}$, or both $\mathrm{N}$ and $\mathrm{P}$ (for prediction 2).

Linear regressions were used to test the following: (1) if TDN, TP, DIN and DIN:TP (i.e., nutrient limitation regime) and Chl- $a$ and seston $\mathrm{C}$ (phytoplankton quantity) were related to DOC (for predictions 3 and 4); (2) if Chl- $a$ and seston $\mathrm{C}$ were related to nutrients (TDN, TP, DIN) (for prediction 3); and (3) if Chl- $a$ and seston $\mathrm{C}, \mathrm{C}: \mathrm{P}$ and $\mathrm{N}: \mathrm{P}$ were related to DIN:TP (i.e., lake nutrient limitation regime) or SUVA (i.e., water color and, hence, light conditions) (for predictions 3 and 5). Absorbance at 365 and $440 \mathrm{~nm}$ of lake water were strongly and positively correlated with SUVA $\left(\log _{10}\left(\right.\right.$ Absorbance $\left._{365}\right)=0.87+1.57 \times \log _{10}(\mathrm{SUVA}), R^{2}=0.89$, $P<0.001 ; \log _{10}\left(\right.$ Absorbance $\left._{440}\right)=0.62+1.72 \times \log _{10}($ SUVA $)$, $R^{2}=0.94, P<0.001$ ), thus, SUVA was used to represent both DOC composition and changes in light conditions.

Analysis of covariance (ANCOVA) was used to test if seston C:P and N:P changed with lake DIN:TP and SUVA, and if these relationships differed between mountain regions (for predictions 3 and 5). Mountain region was used as the fixed factor, with DIN:TP and SUVA as the covariates in ANCOVA.

Linear regressions were used to test if ARA, EPA, DHA and the FA groups of seston were associated with lake DIN:TP and SUVA (for predictions 3 and 5). Initially, ANCOVA was also used to assess whether concentrations of seston FA (or FA groups) were related to lake DIN:TP or SUVA, and whether the relationships differed between Abisko and Jämtland lakes. However, the results of the ANCOVA relating seston FA to lake DIN:TP showed no significant mountain region effect $\left(F_{1,11}=0.06-2.56\right.$, all $P \geq 0.14)$ and no interaction between mountain region and DIN:TP $\left(F_{1,11}=0.09-4.71\right.$, all $\left.P \geq 0.05\right)$. Thus, we proceeded to use only linear regressions for seston FA with lake DIN:TP. For seston $\omega 3: \omega 6$ FA ratio and LongSAFA, the Abisko and Jämtland lakes appeared as distinct groups along the SUVA gradient, and no significant relationship between these FA groups with SUVA in individual mountain regions was detected in ANCOVA $\left(F_{1,11}=0.02-0.20\right.$, all $\left.P \geq 0.66\right)$. Hence, we used only t-tests to compare seston $\omega 3: \omega 6$ FA ratio and LonSAFA between mountain regions.

Stepwise multiple regressions with forward selection was conducted to identify the environmental variables (i.e., DOC, TDN, TP, DIN:TP, SUVA and \%Chl) that best 
explained the seston FA (for predictions 3 and 5). In each test, the model with the lowest corrected Akaike information criterion (AICc) was selected as the best model. All t-tests, one-way ANOVA, regressions, ANCOVA and multiple regressions were conducted using Sigma Plot 14.0 and $\mathrm{JMP}^{\circledR}$ version 14.01. Statistical significance was defined at $P<0.05$.

\section{Results}

\section{Long-term trends in $\mathrm{N}$-deposition and lake water chemistry}

There was a declining trend in DIN deposition in the longterm monitoring data in both mountain regions, with a steeper rate of decline in the northern mountain region than in the southern one (Sen slope $-9.23 \mathrm{~kg}$ ha year ${ }^{-2}$ in Abisko, $P=0.0002$; Sen slope $-6.68 \mathrm{~kg}$ ha year ${ }^{-2}$, $P=0.041$ ) (Fig. 1). Deposition in Abisko was consistently lower than in Jämtland (t-test, $P<0.05$ ) by approximately $50-100 \mathrm{~kg}$ ha year ${ }^{-2}$, decreasing from approximately 300 to $150 \mathrm{~kg}$ ha year ${ }^{-1}$ in Jämtland, and from 200 to $70 \mathrm{~kg}$ ha year ${ }^{-1}$ in Abisko. Lake DIN and TP declined in both mountain regions, and these declines were significant except for lake DIN in Abisko $(P=0.075)$. The relative declines in DIN and TP were similar in the two mountain regions. Despite changes in both DIN and TP, $\log _{10}$ (DIN:TP) had no significant trend over the study period.

\section{Catchment characteristics-study lakes}

The study lakes had surface areas ranging from 0.6 to 69.3 ha (from 0.006 to $0.69 \mathrm{~km}^{2}$ ), with no significant difference in mean lake area between mountain regions (t-test; $P=0.87)$. Mean catchment area and drainage ratios did not differ significantly between mountain regions (t-tests, $P=0.15$ and 0.09, respectively). Catchments in Abisko had steeper slopes with less vegetation (16-48\% cover) that were dominated by deciduous forest compared to gentler slopes that were completely covered by vegetation $(100 \%$ cover $)$ that was dominanted by deciduous forest but with elements of coniferous forest and wetlands in Jämtland (Table 1).

\section{Lake water chemistry}

Mean epilimnetic water temperatures ranged between 9.9 and $14.9^{\circ} \mathrm{C}$ (Table S1) and lakes were overall colder in Abisko $\left(11.7^{\circ} \mathrm{C}\right)$ than in Jämtland $\left(14.3^{\circ} \mathrm{C}\right)$ over summer (t-test, $P<0.001)$. The study lakes varied in nutrient (TDN: $62-387 \mu \mathrm{g} \mathrm{L}^{-1}$; DIN: 4-24 $\mu \mathrm{g} \mathrm{L}^{-1}$; TP: 3-8 $\mu \mathrm{g} \mathrm{L}^{-1}$ ) and DOC (1.9-7.2 $\mathrm{mg} \mathrm{L}^{-1}$ ) concentrations (Table S1), with no significant differences in mean lake DOC and TP concentrations between mountain regions (t-tests; $P=0.49$ and 0.39 ; respectively). The TDN concentrations were, however, higher in Abisko (mean $=231 \mu \mathrm{g} \mathrm{L}^{-1}$ ) than in Jämtland (mean $=143 \mu \mathrm{g} \mathrm{L}^{-1}$ ) (t-test, $\left.P<0.001\right)$. TP and TDN were correlated and tended to increase with DOC in both mountain regions, but this was only significant for TDN (linear regressions: $R^{2}=0.58$ (Abisko) and 0.97 (Jämtland); $P<0.05$ for both). The DIN concentrations were significantly lower in Abisko (median $5.7 \mu \mathrm{g} \mathrm{L}^{-1}$ ) than in Jämtland (median $\left.=10.9 \mu \mathrm{g} \mathrm{L}^{-1}\right)($ Mann-Whitney test; $P<0.001)$. The mean $\log$ DIN:TP ratios were significantly lower in Abisko (0.39) than in Jämtland (0.79) (t-test; $P=0.003)$, and distributed in a similar pattern as for DIN across the lake DOC gradients (Fig. 2a). Lakes in Jämtland had significantly higher absorbance at $250 \mathrm{~nm}\left(\right.$ mean $\left.=0.25 \mathrm{~cm}^{-1}\right)$, SUVA $\left(\right.$ mean $\left.=0.047 \mathrm{~L} \mathrm{mg} \mathrm{C} \mathrm{cm}^{-1}\right)$, and $\mathrm{k}_{\mathrm{d}}\left(\right.$ mean $=1.04 \mathrm{~m}^{-1}$ ) compared to the Abisko lakes (mean $\mathrm{Abs}_{250}=0.113 \mathrm{~cm}^{-1}$; mean SUVA $=0.021 \mathrm{~L} \mathrm{mg} \mathrm{C} \mathrm{cm}^{-1}$; mean $\mathrm{k}_{\mathrm{d}}=0.66 \mathrm{~m}^{-1}$ ) (Mann-Whitney and t-tests; $P<0.05$ ). DOC was linearly related with absorbance at $250 \mathrm{~nm}$ in both regions but with a steeper slope in Jämtland (ABS250 $=-0.0466+(0.0587$ $\times$ DOC) $\left.; R^{2}=0.99 P<0.001\right)$ compared to in Abisko (AB $\mathrm{S} 250=-0.0696+\left(0.0349 \times \mathrm{DOC} ; R^{2}=0.80 ; P=0.03\right)$. Hence, the DOC was subsequently less aromatic and more TDN-rich in Abisko compared to the DOC in Jämtland, whereas the Jämtland lakes were enriched with DIN, with higher DIN:TP ratios, compared to the Abisko lakes.

\section{Phytoplankton nutrient limitation regimes}

In Abisko, the one-way ANOVA applied to pooled seasonal lake means for each bioassay response variable and region (Fig. 2b) revealed that the lakes were clearly N- to NP-limited over summer. Hence in Abisko, RR_N and RR_NP were significantly higher than the control, whereas RR_P did not differ from the control. In addition, treatment with $\mathrm{N}$ and $\mathrm{P}$ combined (RR_NP) gave significantly higher response than single $\mathrm{N}$ treatment (RR_N), and the treatment with $\mathrm{P}$ addition alone showed the lowest response (one-way ANOVA: $F_{2,21}=46.46, P<0.001$; Tukey tests: all $P<0.01$; Fig. 2 b). In Jämtland lakes, addition of $\mathrm{N}$ - and P-alone (RR_N, RR_P) gave similar responses relative to the control, and response to NP co-additions was significantly higher than the control, indicating that the lakes were dual-limited by $\mathrm{N}$ and $\mathrm{P}$. The NP treatment (RR_NP) gave significantly higher responses than single $\mathrm{N}$ and single $\mathrm{P}$ treatments (one-way ANOVA: $F_{2,18}=9.08, P=0.002$; Tukey tests: all $P<0.01$; Fig. 2 b), but sole $\mathrm{N}$ or $\mathrm{P}$ addition resulted in similar responses (Tukey test: $P=0.97)$. The relative degree of $\mathrm{N}$ - and P-limitation (RR_N:RR_P) was related to the DIN:TP ratio (Fig. 2c). In our bioassay experiments, $\mathrm{N}$-limitation predominated at DIN:TP ratios $<3.3$, and P-limitation predominated at DIN:TP ratios $>7.5$. In between these threshold ratios, 
Fig. 2 a Lake dissolved inorganic nitrogen to total phosphorus ratio (DIN:TP; $\log _{10}$-transformed) against dissolved organic carbon (DOC) concentration of the study lakes, $\mathbf{b}$ pooled mean response ratios for each lake and each region for N, P and NP treatments (RR_N, RR_P, RR_NP; $\log _{10}$-transformed) from the bioassays experiments conducted in Abisko (2016) and Jämtland (2017). Within each region, different letters indicate significant differences by one-way ANOVA and posthoc Tukey tests. The line within the box show median, the box 25 and $75 \%$ precentiles, and the whisker 10 and $90 \%$ precentiles. The dotted reference line at $\log R R=0$ indicates the responses in treatments and control were the same. $\mathbf{c}$ Phytoplankton RR_N:RR_P ratios against lake DIN:TP (both $\log _{10}$-transformed). Horizontal and vertical dotted lines in a and $\mathbf{c}$, respectively, indicate DIN:TP thresholds of nutrient limitation regimes for phytoplankton: N-limitation $<3.3$, NP-limitation 3.3-7.5, P-limitation $>7.5$

phytoplankton tended to be NP co-limited. In Abisko, 5 out of 8 lakes were N-limited, and 3 out of 8 lakes were NPlimited. In Jämtland, 6 out of 7 lakes were NP-limited, and 1 out of 7 lakes was P-limited (Fig. 2c). The NP-limited lakes in Abisko, and the P-limited lake in Jämtland, were all low DOC lakes with high DIN:TP ratios (Fig. 2a, c).

\section{Phytoplankton and seston quantity and quality}

The epilimnetic Chl- $a$, seston $\mathrm{C}$ and the proportion of phytoplankton $\mathrm{C}$ in seston $\mathrm{C}$ (i.e., \% $\mathrm{Chl}$ ) of the study lakes ranged between $0.5-1.4 \mu \mathrm{g} \mathrm{L}^{-1}, 206-592 \mu \mathrm{g} \mathrm{L}^{-1}$ and 8-27\% (Table S2). The concentrations, or proportions, were similar between the two regions; Abisko, means: Chl$a=0.93 \mu \mathrm{g} \mathrm{L}^{-1}$; seston $\mathrm{C}=368 \mu \mathrm{g} \mathrm{L}^{-1}$; \%Chl=13\%; Jämtland, means: Chl- $a=0.99 \mu \mathrm{g} \mathrm{L}^{-1}$; seston $\mathrm{C}=417 \mu \mathrm{g} \mathrm{L}^{-1}$; $\% \mathrm{Chl} a=14 \%$ (t-tests: $P=0.51,0.41$, and 0.85 , respectively). The Chl- $a$ :TP ratios (Table S2) were somewhat lower in Abisko (0.235) than in Jämtland (0.267), but did not differ significantly between regions (t-test, $P=0.42$ ). Chl- $a$ tended to increase with increased DOC and TP concentrations, but these relationships were not statistically significant (linear regressions: $R^{2}=0.17$ and $0.14 ; P=0.14$ and 0.17 , respectively). However, seston $\mathrm{C}$ concentrations increased with increasing DOC in both regions (linear regression for Abisko and Jämtland: $R^{2}=0.54$ and $0.55 ; P=0.04$ and 0.05 ; respectively). The seston $\mathrm{C}: \mathrm{P}$ and $\mathrm{N}: \mathrm{P}$ ratios ranged between 329-656 and 29-64, respectively (Table S2). In Jämtland seston C:P tended to increase with increased DIN:TP, but this trend was not significant (linear regression, $R^{2}=0.29$; $P=0.22$ ). There were no such trends in Abisko between seston C:P and lake DIN:TP (linear regression, $R^{2}=0.13$; $P=0.38)$. Results from ANCOVA also showed that, in individual regions, seston $\mathrm{C}: \mathrm{P}$ and $\mathrm{N}: \mathrm{P}$ were not correlated significantly with lake DIN:TP $\left(F_{1,11}=0.17\right.$ and $0.56, P=0.69$ and 0.47 , respectively). Also, there was no significant interaction between region and lake DIN:TP on seston C:P and $\mathrm{N}: \mathrm{P}\left(F_{1,11}=2.08\right.$ and $2.71, P=0.18$ and 0.13 , respectively $)$. Seston C:P and N:P were negatively related with SUVA in
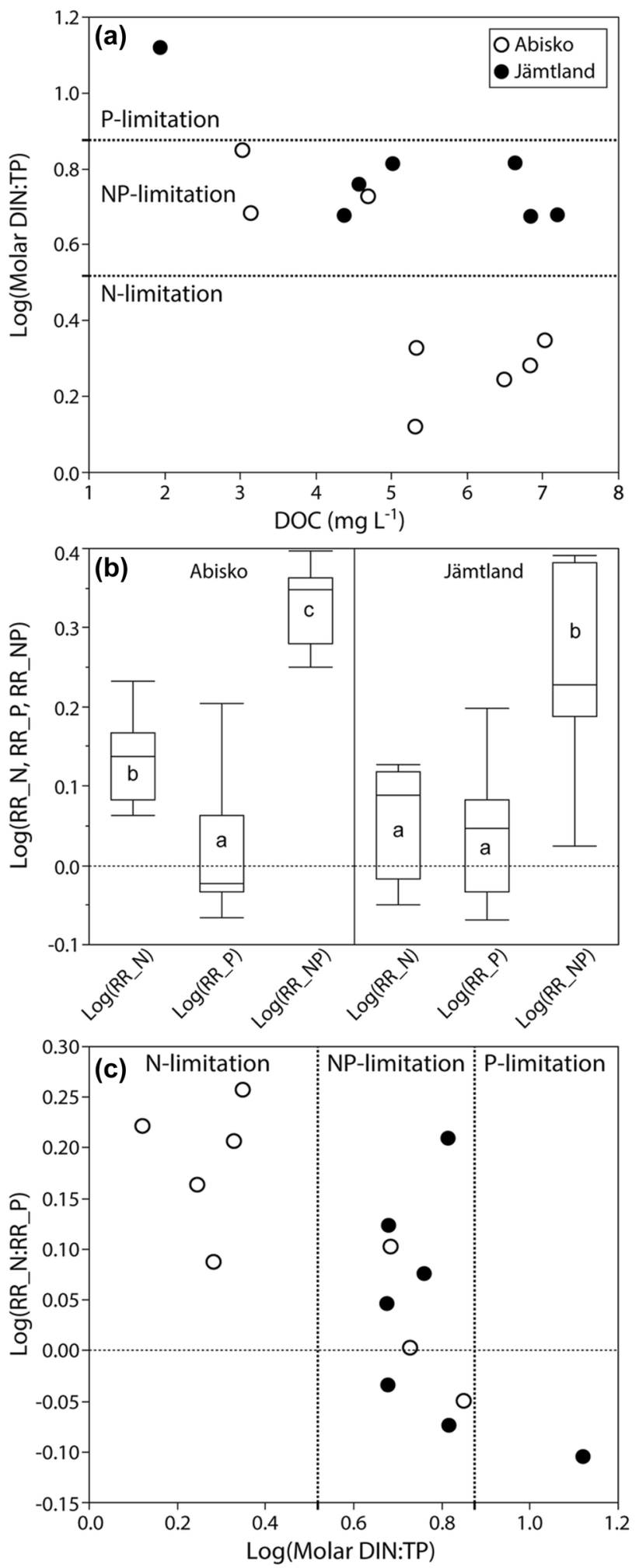

both regions, and significantly different between regions, with higher seston C:P and N:P ratios in Jämtland (means: 503 and 49) than in Abisko (means: 410 and 36) lakes (t-tests, $P=0.005$ and 0.002) (Tables 3, S2; Fig. 3). Yet, there was no interaction between region and SUVA, such 


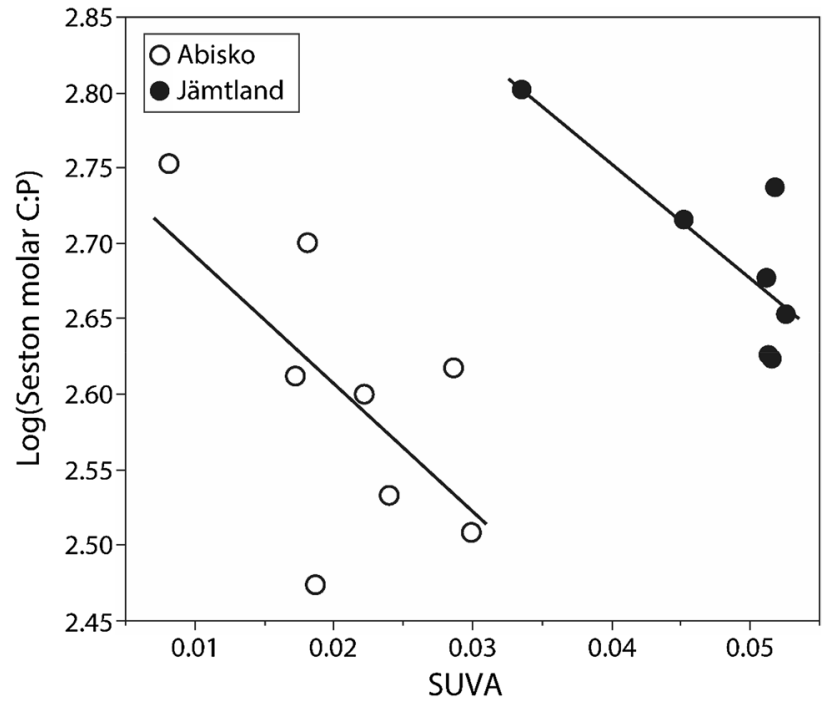

Fig. 3 a Seston C:P and $\mathbf{b} \mathrm{N}: \mathrm{P}$ (both $\log _{10^{-}}$-transformed) against specific ultraviolet absorbance (SUVA) of lake water. Lines of fit are indicated for lakes in individual regions. See Table 3 for ANCOVA results

that slopes of the linear relationships of seston C:P and N:P with SUVA did not differ between regions (Table 3; Fig. 3).

\section{Fatty acid quantity and composition}

A total of 28 FA were identified in the seston samples. Seasonal averages of seston total FA in individual lakes ranged from 17.6 to $76.0 \mathrm{mg} \mathrm{FA} \mathrm{g}^{-1}$ seston $\mathrm{C}$ in Abisko and from
32.5 to $67.4 \mathrm{mg} \mathrm{FA} \mathrm{g}^{-1}$ seston $\mathrm{C}$ in Jämtland lakes, but did not differ between the mountain regions (t-test, $P=0.23$ ). Seston concentrations of EPA, DHA, $\omega 3, \omega 6$, total PUFA, and total FA increased with increasing DIN:TP (Table 4; Figs. 4, S1). DIN:TP together with \%Chl were the main predictors of these seston FA (Table 5). Seston EPA and DHA were predicted to increase from 0.59 to $3.11 \mathrm{mg} \mathrm{FA} \mathrm{g}^{-1}$ seston $\mathrm{C}$ and from 0.41 to $1.35 \mathrm{mg} \mathrm{FA} \mathrm{g}^{-1}$ seston $\mathrm{C}$, respectively, when DIN:TP increased from 1.3 to 13.2 based on the linear models (Table 4; Fig. 4a). Seston EPA, $\omega 6$ and total PUFA concentrations were lower in Abisko than in Jämtland lakes (t-tests, $P=0.02-0.04$ ), while seston DHA and $\omega 3$ did not differ between regions (t-tests $P=0.21$ and 0.17 , respectively) (Table 2; Fig. S2).

LongSAFA, SAFA, MUFA and total FA concentrations in seston increased with increasing DIN:TP (Table 5). Seston $\omega 3: \omega 6$ FA ratio and BAFA did not change with DIN:TP, but decreased with increasing lake SUVA (Tables 4, 5). Yet, seston LongSAFA and MUFA were positively associated with SUVA (Table 5). Based on our SUVA data, the DOC had higher aromaticity in Jämtland lakes than in Abisko lakes (Fig. 5), despite similar range of DOC concentration in the two regions. Thus, increasing DOC aromaticity (and decreasing light availability) in our study lakes led to reductions in the overall seston quality. With increasing SUVA, seston MUFA and BAFA changed minimally in Abisko lakes, but decreased substantially in Jämtland lakes (Table 3; Fig. 5a, b). Seston MUFA was mainly dominated by oleic acid (cis-18:1 $\omega 9)$. Overall, seston $\omega 3: \omega 6$ and BAFA were higher (t-tests, $P=0.03$ and $<0.001$, respectively), but

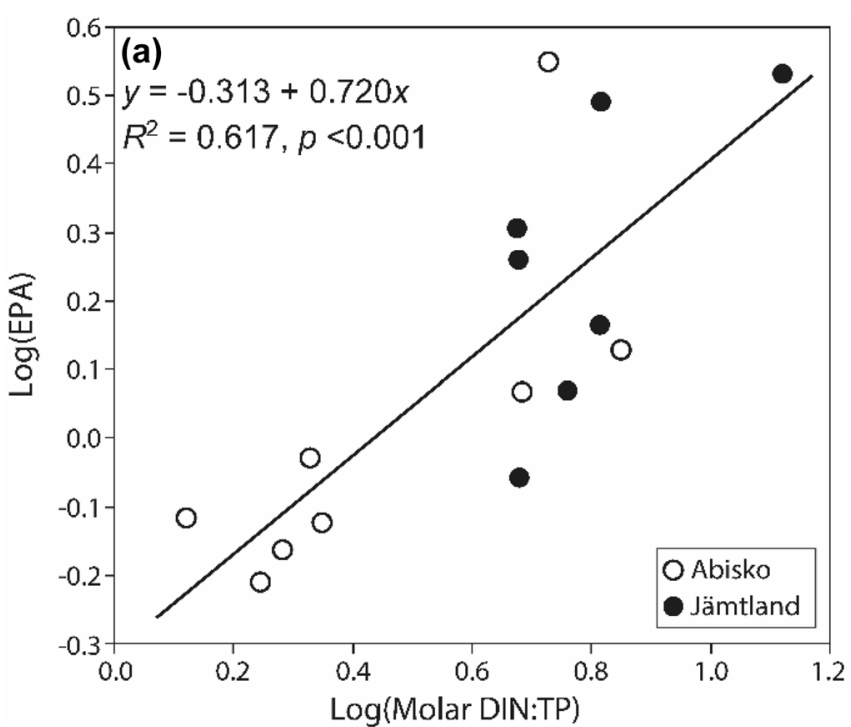

Fig. 4 Linear regressions of seston a EPA and b total polyunsaturated fatty acid (PUFA) concentrations (mg FA g ${ }^{-1}$ seston C; $\log _{10}$-transformed) with lake dissolved inorganic nitrogen to total phosphorus ratio (DIN:TP; $\log _{10}$-transformed). See Table 1 for FA

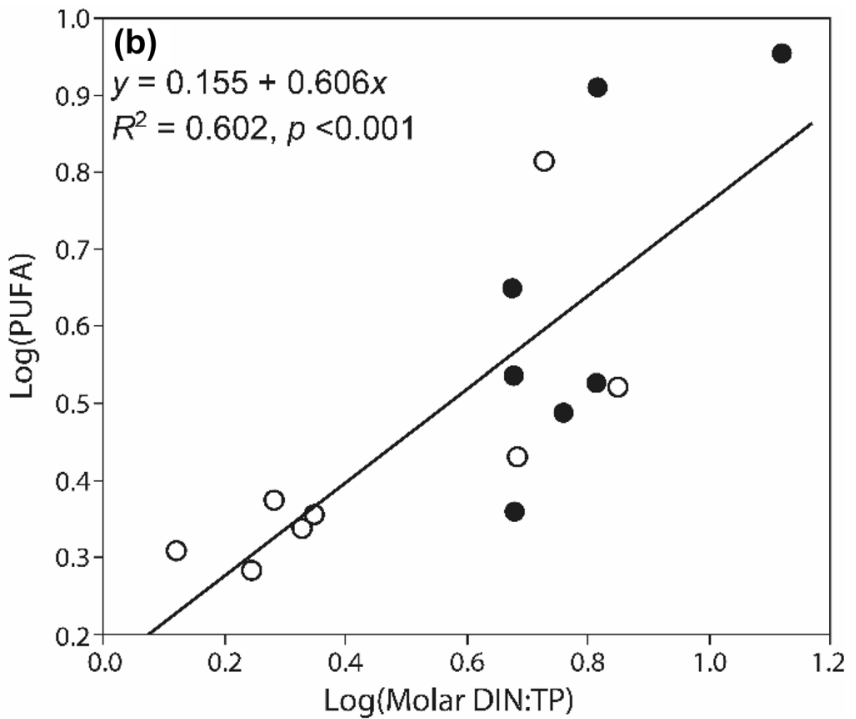

abbreviations. Linear regressions were used, as ANCOVA detected no significant region effect nor interaction bewteen region and DIN:TP on seston FA. See data analysis section for statistical details 
Table 2 Fatty-acid (FA) concentrations ( $\mathrm{mg} \mathrm{FA} \mathrm{g}^{-1}$ seston C) of seston from eight Abisko and seven Jämtland lakes

\begin{tabular}{|c|c|c|c|c|}
\hline \multirow[t]{2}{*}{ Region $(n)$} & \multicolumn{2}{|c|}{ Abisko (8) } & \multicolumn{2}{|c|}{ Jämtland (7) } \\
\hline & Mean & SD & Mean & SD \\
\hline Total fatty acids & 38.64 & 21.93 & 45.86 & 12.24 \\
\hline SAFA & 33.72 & 20.30 & 35.67 & 7.15 \\
\hline ShortSAFA & 33.09 & 20.17 & 31.70 & 7.08 \\
\hline $12: 0$ & 0.36 & 0.08 & 1.04 & 0.28 \\
\hline 13:0 & 0.12 & 0.02 & 0.20 & 0.07 \\
\hline $14: 0$ & 1.49 & 0.43 & 1.48 & 0.45 \\
\hline $15: 0$ & 0.31 & 0.06 & 0.65 & 0.19 \\
\hline $16: 0$ & 14.04 & 8.19 & 6.52 & 2.83 \\
\hline $17: 0$ & 0.17 & 0.05 & 14.97 & 2.59 \\
\hline 18:0 & 16.59 & 11.64 & 6.84 & 2.74 \\
\hline LongSAFA & 0.64 & 0.14 & 3.97 & 0.43 \\
\hline $20: 0$ & 0.20 & 0.06 & 0.30 & 0.07 \\
\hline 21:0 & 0 & 0 & 0.61 & 0.08 \\
\hline $22: 0$ & 0 & 0 & 0.98 & 0.13 \\
\hline 23:0 & 0.40 & 0.09 & 1.68 & 0.33 \\
\hline $24: 0$ & 0.04 & 0.01 & 0.41 & 0.13 \\
\hline MUFA & 1.09 & 0.38 & 5.13 & 2.47 \\
\hline $14: 1 \omega 5$ & 0.09 & 0.03 & 0.36 & 0.12 \\
\hline $16: 1 \omega 7$ & 0 & 0 & 0.42 & 0.14 \\
\hline $18: 1 \omega 9 c$ & 0.49 & 0.19 & 2.49 & 2.00 \\
\hline $18: 1 \omega 9 t$ & 0.07 & 0.02 & 0.29 & 0.10 \\
\hline $22: 1 \omega 9$ & 0.29 & 0.10 & 0.95 & 0.20 \\
\hline 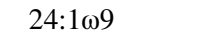 & 0.14 & 0.06 & 0.62 & 0.18 \\
\hline BAFA & 0.91 & 0.18 & 0.23 & 0.12 \\
\hline iso15:0 & 0.33 & 0.06 & 0 & 0 \\
\hline anteiso15:0 & 0.45 & 0.10 & 0 & 0 \\
\hline iso16:0 & 0.05 & 0.02 & 0.23 & 0.12 \\
\hline iso17:0 & 0.08 & 0.02 & 0 & 0 \\
\hline PUFA & 2.91 & 1.52 & 4.82 & 2.65 \\
\hline$\omega 3$ & 2.19 & 1.33 & 3.15 & 1.59 \\
\hline $18: 3 \omega 3$ (ALA) & 0.30 & 0.09 & 0.14 & 0.04 \\
\hline $20: 5 \omega 3$ (EPA) & 1.23 & 0.97 & 1.98 & 0.95 \\
\hline $22: 6 \omega 3$ (DHA) & 0.66 & 0.29 & 1.03 & 0.63 \\
\hline$\omega 6$ & 0.73 & 0.21 & 1.67 & 1.12 \\
\hline $18: 2 \omega 6 \mathrm{c}(\mathrm{LIN})$ & 0.36 & 0.13 & 0.25 & 0.11 \\
\hline $20: 4 \omega 6$ (ARA) & 0.16 & 0.05 & 0.18 & 0.07 \\
\hline $20: 2 \omega 6$ & 0.20 & 0.05 & 1.24 & 1.00 \\
\hline$\omega 3: \omega 6$ & 2.86 & 0.61 & 2.11 & 0.59 \\
\hline
\end{tabular}

Averages among sampling occasions of individual lakes were used to calculate the regional means and SDs

$A L A$ alpha-linolenic acid, $A R A$ arachidonic acid, DHA docosahexaenoic acid, EPA eicosapentaenoic acid, LIN linoleic acid, SAFA total saturated FA, ShortSAFA and LongSAFA total short- $(<20 \mathrm{C})$ and long-chain $(\geq 20 \mathrm{C})$ SAFA respectively, MUFA total monounsaturated FA, BAFA total bacterial FA, PUFA total polyunsaturated FA, $\omega 3$ and $\omega 6$ total omega-3 and omega-6 PUFA respectively, $\omega 3: \omega 6 \omega 3$ to $\omega 6$ FA ratio
LongSAFA and MUFA concentrations were lower (t-tests, both $P<0.001$ ), in Abisko than in Jämtland lakes (Table 2; Fig. S2a). Seston ShortSAFA and SAFA concentrations were not different between regions (t-tests, $P=0.68$ and 0.40, respectively) (Table 2; Fig. S2a).

\section{Discussion}

We found that $\mathrm{N}$ deposition and lake nutrient (DIN, TP) concentrations have declined during the last two decades (supporting prediction 1), but that lake DIN:TP stoichiometry has not changed (not supporting prediction 1), indicating that Swedish mountain lakes are becoming more nutrient poor but with small changes in N:P stoichiometry. The thresholds in DIN:TP ratios where phytoplankton were found to be $\mathrm{N}$ and NP-limited (DIN:TP ratio was $<3.3$ for N-limitation, 3.3-7.5 for NP-limitation, and $>7.5$ for P-limitation) were similar to those thresholds identified by Bergström (2010). Differences in phytoplankton nutrient limitation could be linked to magnitudes in $\mathrm{N}$ deposition and its influence on lake DIN:TP ratios, i.e., phytoplankton were primarily NP-limited in the southern Jämtland lakes with higher N deposition (and DIN:TP ratios), and N- to NP-limited in the northern Abisko lakes with lower $\mathrm{N}$ deposition (and DIN:TP ratios); hence partly in line with prediction 2 .

The $\mathrm{N}$ fertilization effect induced by higher $\mathrm{N}$ deposition was, however, low when considering the responses of phytoplankton quantity (Chl- $a$ and seston C) (not supporting prediction 2). Higher $\mathrm{N}$ deposition and higher DIN:TP ratios in Jämtland lakes promoted NP-limitation in phytoplankton, and lower $\mathrm{N}$ deposition and lower DIN:TP ratios in Abisko lakes promoted $\mathrm{N}$ - to NP-limitation in phytoplankton. Thus, the difference in $\mathrm{N}$ deposition and its impacts on the DIN:TP ratios in Jämtland lakes were not high enough to shift phytoplankton to P-limitation (with one exception). This is likely why phytoplankton quantity (Chl- $a$, seston C) and Chl- $a$ :TP ratios were similar in the two mountain regions (Table S2); i.e., the $\mathrm{N}$ fertilization effect induced by $\mathrm{N}$ deposition was insufficient to substantially boost phytoplankton quantity.

However, the long-term trends showed that $\mathrm{N}$ deposition was substantially higher in 1997-2006 than in 2007-2017 (Fig. 1), which may explain why phytoplankton in bioassay experiments were found to be P-limited in Jämtland in 2003 (Vrede and Tranvik 2006). In the Jämtland mountain region, $\mathrm{N}$ deposition was more than twice as high in 2003 (316 $\mathrm{mg} \mathrm{N} \mathrm{m}^{-2}$ year $^{-1}$ ) compared to that in 2017 (147 $\mathrm{mg} \mathrm{N} \mathrm{m}^{-2}$ year $^{-1}$ ), implying that the reduction in $\mathrm{N}$ deposition during this time period has changed the nutrient limitation regime in phytoplankton from P- to NP-limitation, corresponding to reported widespread shifts in nutrient limitation regimes in Swedish lakes (Isles et al. 2018). The mean Chl- $a$ :TP ratio $(0.487 \pm 0.104)$ for the Jämtland 
Table 3 ANCOVA comparisons of seston $\mathrm{C}: \mathrm{P}$ and $\mathrm{N}: \mathrm{P}$, and monounsaturated (MUFA) and bacterial fatty-acid (BAFA) concentrations ( $\mathrm{mg} \mathrm{FA} \mathrm{g}^{-1}$ seston C) between Abisko and Jämtland lakes across the gradient in specific ultraviolet absorbance (SUVA)

\begin{tabular}{llllrrr}
\hline Variable & DF $_{\text {Effect }}$ & DF $_{\text {Error }}$ & \multicolumn{1}{l}{ SS } & \multicolumn{1}{l}{$F$} & Model $R_{2}$ \\
\hline Log(Seston C:P) & & & & & & 0.496 \\
Region & 1 & 11 & 0.064 & 15.034 & 0.003 & \\
SUVA & 1 & 11 & 0.040 & 9.364 & 0.011 & \\
Region*SUVA & 1 & 11 & 0.000 & 0.028 & 0.871 & \\
Log(Seston N:P) & & & & & 0.585 \\
Region & 1 & 11 & 0.074 & 20.175 & 0.001 & \\
SUVA & 1 & 11 & 0.044 & 11.970 & 0.005 & \\
Region*SUVA & 1 & 11 & $<0.001$ & 0.002 & 0.966 & \\
Log(MUFA) & & & & & & 0.903 \\
Region & 1 & 11 & 0.707 & 53.064 & $<0.001$ & \\
SUVA & 1 & 11 & 0.087 & 6.507 & 0.027 & \\
Region*SUVA & 1 & 11 & 0.096 & 7.209 & 0.021 & \\
Log(BAFA) & & & & & & 0.961 \\
Region & 1 & 11 & 0.050 & 10.755 & 0.007 & \\
SUVA & 1 & 11 & 0.103 & 21.871 & 0.001 & \\
Region*SUVA & 1 & 11 & 0.127 & 27.034 & $<0.001$ & \\
\hline
\end{tabular}

All response variables were $\log _{10}$-transformed

SS sum of squares
Table 4 Linear regressions of seston polyunsaturated fatty-acid (FA) concentrations ( $\mathrm{mg} \mathrm{FA} \mathrm{g}^{-1}$ seston $\mathrm{C}$; $\log _{10}$-transformed except for $\omega 3: \omega 6$ FA ratio) with lake dissolved inorganic nitrogen to total phosphorusratios (DIN:TP; $\log _{10}$-transformed)

\begin{tabular}{lllll}
\hline Fatty acid & Regression & $F_{1,13}$ & $P$ & $R^{2}$ \\
\hline$x=\log ($ DIN:TP) & & & & \\
$\log ($ ARA $)$ & NA & 3.063 & 0.104 & NA \\
$\log ($ EPA $)$ & $y=-0.313+0.720 x$ & 20.945 & $<0.001$ & 0.617 \\
$\log ($ DHA $)$ & $y=-0.450+0.519 x$ & 10.867 & 0.006 & 0.455 \\
$\log (\omega 3)$ & $y=0.021+0.569 x$ & 15.402 & 0.002 & 0.542 \\
$\log (\omega 6)$ & $y=-0.419+0.671 x$ & 18.327 & $<0.001$ & 0.585 \\
$\log ($ PUFA $)$ & $y=0.155+0.606 x$ & 19.682 & $<0.001$ & 0.602 \\
$\omega 3: \omega 6$ & NA & 0.644 & 0.437 & NA \\
$\log ($ Total $)$ & $y=1.264+0.527 x$ & 17.784 & 0.001 & 0.578 \\
\hline
\end{tabular}

Model equations and $R^{2}$ are shown for significant regressions only $(P<0.05)$

NA not applicable, Total total FA concentration. See Table 1 for other FA abbreviations

lakes included in the study by Vrede and Tranvik (2006) was almost twice as high as the Chl- $a$ :TP ratio found in our Jämtland lakes in $2017(0.267 \pm 0.16)$, suggesting that the reduction in $\mathrm{N}$ deposition resulted in reduced phytoplankton biomass development per phosphorus unit in this mountain region. In contrast, N deposition in Abisko in 2004-2005 was slightly higher (182-207 $\mathrm{mg} \mathrm{N} \mathrm{m}^{-2}$ year $^{-1}$ ) compared to the deposition in $2016\left(123 \mathrm{mg} \mathrm{N} \mathrm{m}^{-2}\right.$ year $\left.^{-1}\right)$, and the mean Chl- $a$ :TP ratios in 2004-2005 and $2016(0.209 \pm 0.106$ and $0.225 \pm 0.095$; i.e., data from Bergström et al. 2008 and this study) were similar, suggesting that the reduction in $\mathrm{N}$ deposition did not affect nutrient limitation regime or phytoplankton biomass development. The current Chl- $a$ concentrations in our mountain lakes [range from 0.5 to $1.4 \mu \mathrm{g} \mathrm{L}^{-1}$, which is about $25-75 \mu \mathrm{g} \mathrm{C} \mathrm{L}^{-1}$ in phytoplankton biomass (cf. Ahlgren 1983)], is close to the estimated threshold of $50 \mu \mathrm{g} \mathrm{C} \mathrm{L}{ }^{-1}$ for maintenance metabolism for some zooplankton (i.e., Daphnia and Eudiaptomus) (Lampert 1977; Andersen 1997; Sterner 1997). The low \%Chla (8-27\%) in seston also illustrates that large shares of the seston $\mathrm{C}$ was detritus from terrestrial and/or bacteria, which is common in oligotrophic lakes (Hessen et al. 2003). Thus, the slight reduction in phytoplankton biomass following reduced $\mathrm{N}$ deposition in the Jämtland mountain region may have moved these lakes to reach critically low levels of phytoplankton biomass for zooplankton.

The $\mathrm{N}$ fertilization effect induced by higher $\mathrm{N}$ deposition, causing higher DIN:TP ratios, was stronger when considering the responses of phytoplankton quality, i.e., there was a negative effect on seston C:P and N:P (i.e., increased seston $\mathrm{C}: \mathrm{P}$ and $\mathrm{N}: \mathrm{P}$ ) and a positive effect on PUFA content (increased PUFA content) (supporting prediction 3). PUFA, and especially EPA, in seston increased with increasing lake DIN:TP ratios (Fig. 4) and were best explained by lake DIN:TP ratio together with \% Chl (Tables 4, 5). Laboratory studies have shown that somatic growth and reproduction of zooplankton are strongly limited when seston EPA is below $1.0 \mathrm{mg} \mathrm{FA} \mathrm{g}^{-1}$ seston C (Müller-Navarra et al. 2000). Interestingly, our findings (Fig. 4) suggest that seston EPA was $1.1 \mathrm{mg} \mathrm{FA} \mathrm{g}^{-1}$ seston $\mathrm{C}$, which is very close to this threshold, when lake DIN:TP was 3.3, a DIN:TP ratio that separates N- and NP-limitation in phytoplankton based on 
Table 5 Multiple regressions of seston fatty-acid (FA) concentrations (mg FA g ${ }^{-1}$ seston $\mathrm{C}$; $\log _{10}$-transformed except for $\omega 3: \omega 6$ FA ratio) against lake environmental variables, i.e., dissolved organic carbon (DOC), total dissolved nitrogen (TDN), total phosphorus (TP), dis- solved inorganic nitrogen to TPratio (DIN:TP; $\log _{10}$-transformed), specific ultraviolet absorbance (SUVA), and percentage chlorophyll $a$ per seston C (\% Chl)

\begin{tabular}{|c|c|c|c|c|}
\hline Fatty acid & Coefficient of explanatory variable & Intercept & Model $R^{2}$ & $\mathrm{AIC}_{\mathrm{C}}$ \\
\hline $\log (\mathrm{EPA})$ & $0.580(\log (\mathrm{DIN}: \mathrm{TP}))^{* * *}, 0.030(\% \mathrm{Chl}) * * *$ & $-0.656 * * *$ & $0.894 * * *$ & -23.410 \\
\hline $\log (\mathrm{DHA})$ & 0.428 (Log(DIN:TP) $) *, 0.020(\% \mathrm{Chl}) *$ & $-0.673 * * *$ & $0.569 * *$ & -7.655 \\
\hline $\log (\omega 3)$ & $0.450(\log (\mathrm{DIN}: \mathrm{TP}))^{* * *}, 0.026(\% \mathrm{Chl}) * * *$ & $-0.270 * *$ & $0.811 * * *$ & -19.921 \\
\hline $\log (\omega 6)$ & $0.671(\log (\mathrm{DIN}: \mathrm{TP}))^{* * *}$ & $-0.419 * *$ & $0.585^{* * *}$ & -5.762 \\
\hline Log(PUFA) & $0.503(\log (\mathrm{DIN}: \mathrm{TP}))^{* * *}, 0.022(\% \mathrm{Chl})^{* *}$ & -0.096 & $0.788 * * *$ & -17.880 \\
\hline$\omega 3: \omega 6$ & - 25.920 (SUVA)*, $0.066(\% \mathrm{Chl})^{*}$ & $2.429 * * *$ & $0.424 *$ & 32.168 \\
\hline $\log ($ ShortSAFA) & $-0.096(\mathrm{TP})^{* *}, 0.017(\% \mathrm{Chl})^{*}$ & $1.674 * * *$ & $0.604 * *$ & -11.222 \\
\hline $\log ($ LongSAFA $)$ & $19.919(\mathrm{SUVA})^{* * *}, 0.750(\log (\mathrm{DIN}: \mathrm{TP}))^{* * *}, 0.059(\mathrm{TP})^{*}$ & $-1.213 * * *$ & $0.937 * * *$ & -12.941 \\
\hline $\log (\mathrm{SAFA})$ & $0.326(\log (\mathrm{DIN}: \mathrm{TP}))^{*},-0.070(\mathrm{TP})^{*}$ & $1.625^{* * *}$ & $0.602 * *$ & -11.323 \\
\hline $\log ($ MUFA) & $0.993(\log (\mathrm{DIN}: \mathrm{TP}))^{* * *}, 11.671(\mathrm{SUVA}) * * *, 0.079(\mathrm{TP})^{*}$ & $-1.030 * * *$ & $0.872 * * *$ & -6.067 \\
\hline $\log (\mathrm{BAFA})$ & $-21.521(\mathrm{SUVA}) * * *$ & $0.371 * *$ & $0.850 * * *$ & -10.297 \\
\hline Log(Total) & $0.344(\log (\mathrm{DIN}: \mathrm{TP}))^{*},-0.052(\mathrm{TP})^{*}, 0.013(\% \mathrm{Chl}) *$ & $1.426 * * *$ & $0.718 * * *$ & -13.748 \\
\hline
\end{tabular}

AIC c corrected Akaike information criterion, Total total FA concentration. See Table 1 for other FA abbreviations $* P<0.05, * * P<0.01, * * * P<0.001$

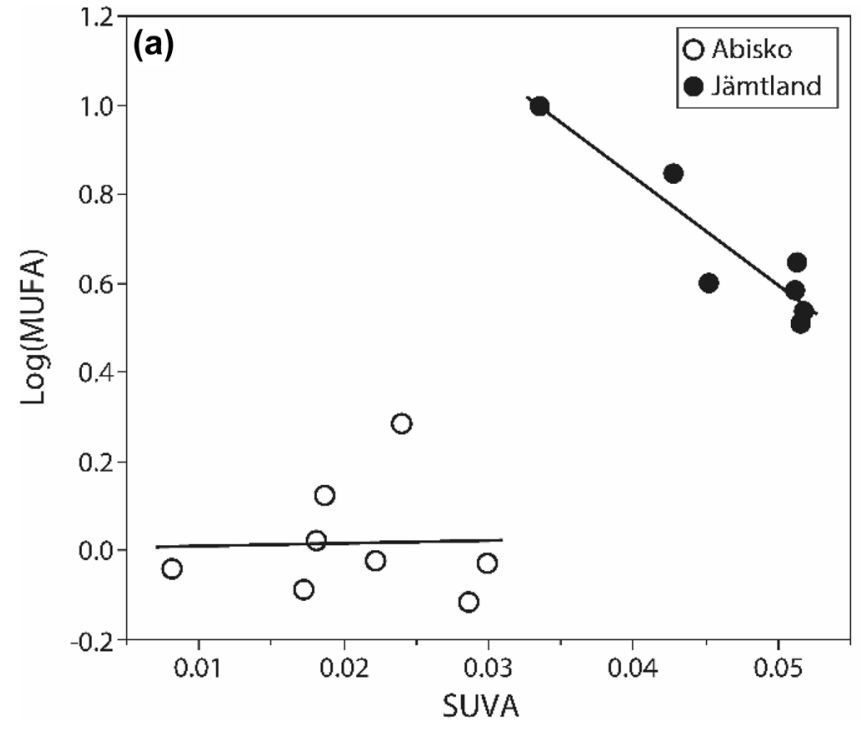

Fig. 5 a Monounsaturated fatty-acid (MUFA) and b bacterial fatty-acid (BAFA) concentrations in seston (mg FA g ${ }^{-1}$ seston $\mathrm{C}$; $\log _{10}$-transformed) against specific ultraviolet absorbance (SUVA) of

bioassay experiments in this and earlier studies (cf. above). Hence, shifting from N- to NP-limitation not only increased the seston EPA content, but also increased it above the threshold level allowing more efficient growth and reproduction of zooplankton. The increases in seston EPA followed the increases in lake DIN:TP and \% Chl- $a$; however, we consider this change was mainly caused by increased biomass and development of dominant species of phytoplankton rather than to be an effect of changes in phytoplankton species composition (cf. Taipale et al. 2013). These lakes

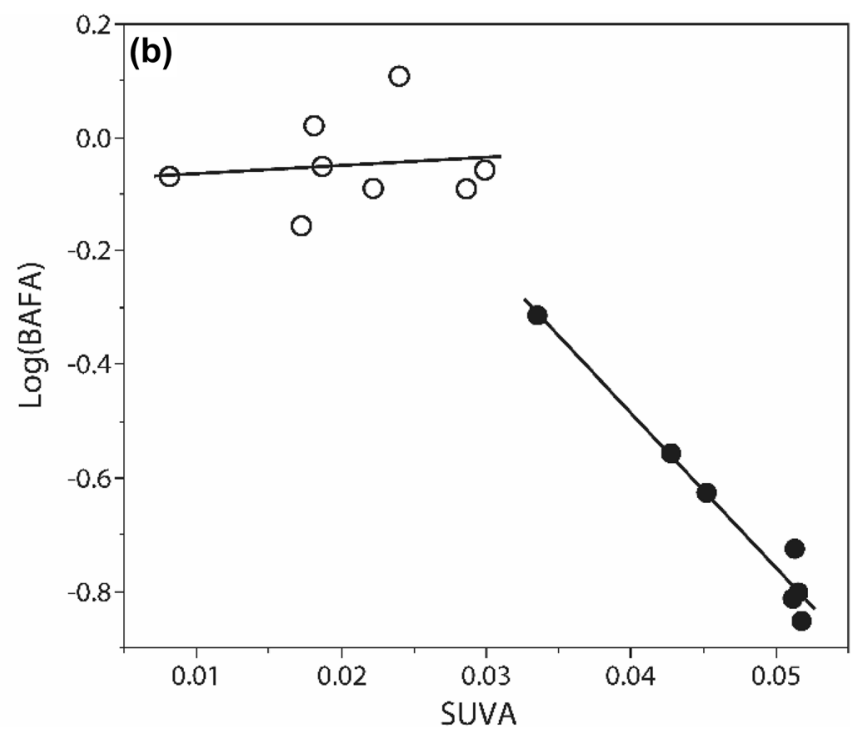

lake water. Lines of fit are indicated for lakes in individual regions. See Table 3 for ANCOVA results

are typically dominated by flagellated cryptophytes, chrysophytes and chlorophytes (Holmgren 1983; Jansson et al. 2010), and results from whole-lake $\mathrm{N}$ fertilization experiments performed in arctic and boreal oligotrophic northern Swedish lakes have shown that it is typically the dominating phytoplankton species that respond to $\mathrm{N}$-enrichment (Holmgren 1983; Deininger et al. 2017).

$\mathrm{N}$ deposition and DIN:TP ratios promoted significantly higher seston $\mathrm{C}: \mathrm{P}$ and $\mathrm{N}: \mathrm{P}$ ratios in Jämtland (south) compared to in Abisko (north) (supporting prediction 3). 
However, the responses in seston $\mathrm{C}: \mathrm{P}$ and $\mathrm{N}: \mathrm{P}$ to elevated DIN:TP ratios differed depending on lake DOC concentration but also on the aromaticity and the quality of the DOC. DIN and DIN:TP ratios were lower in lakes with higher DOC concentration (Fig. 2a), indicating that catchment properties modify the impact of $\mathrm{N}$ deposition on lake DIN:TP ratios by retaining DIN and releasing TP from catchment soils (cf. Bergström et al. 2013; Hessen 2013). In Jämtland and Abisko, the P-limited and NP-limited lakes, respectively, were all low in DOC, suggesting larger impacts from $\mathrm{N}$ deposition on phytoplankton nutrient limitation regimes in the clear than in the more colored mountain lakes (supporting prediction 4). Still, we found no statistically significant trend between increasing lake water DIN:TP and increasing seston C:P and NP ratios in both regions. For Abisko, these results are not so surprising since the DIN:TP ratios were all low and lakes were primarily N-to NP-limited. Hence, one could not expect any increase in seston $\mathrm{C}: \mathrm{P}$ and $\mathrm{N}: \mathrm{P}$ boosted by elevated DIN:TP ratios since $\mathrm{N}$ deposition is low. For Jämtland, however, there was a trend of increasing seston $\mathrm{C}: \mathrm{P}$ and $\mathrm{N}: \mathrm{P}$ with increased lake water DIN:TP, although not statistically significant (cf. above in results). The low statistical power in this relationship might be an effect that few lakes where P-limited and that the range in DIN:TP ratios of the sampled lakes was subsequently low (cf. Fig. 2a).

In both mountain regions seston $\mathrm{C}: \mathrm{P}$ and $\mathrm{N}: \mathrm{P}$ were related to light availability [i.e., negatively related with SUVA with similar declining slopes in each mountain region (Fig. 3)], supporting prediction 5. In line with the light:nutrient hypothesis (Sterner et al. 1997), seston C:P per limiting nutrient was higher in clear than in darker lakes. The fertilization effect from elevated DIN and DIN:TP ratios in Jämtland compared to the Abisko lakes is indicated by higher seston $\mathrm{C}: \mathrm{P}$ (and $\mathrm{N}: \mathrm{P}$ ) ratios, and the highest ratios (in both mountain regions) were found in the low DOC lakes with lowest SUVA (cf. Figs. 2a, 3). Since the light condition was overall better in Abisko (lower SUVA) than in Jämtland, it is likely that changes in seston C:P and $\mathrm{N}: \mathrm{P}$ in the Jämtland lakes were to some extent dampened by the poorer light conditions [i.e., if SUVA had been equally low in Abisko and Jämtland lakes, enhanced DIN:TP ratios should have promoted even higher respons in seston C:P ratio in Jämtland lakes (cf. Sterner et al. 1997)]. The mean seston C:P (419 in Abisko and 498 in Jämtland) were well above the threshold for P limitation in Daphnia (200-300; Sterner and Elser 2002), and in Eudiaptomus (300; Kibby 1971; Hessen and Lyche 1991). Our results are in line with others (Elser et al. 2009b, 2010), illustrating that enhanced $\mathrm{N}$ deposition intensifies P-limitation (Hessen 2013), which may consequently impair food web perfomance by promoting phytoplankton of low $\mathrm{P}$ content. Changes in seston $\mathrm{C}: \mathrm{P}$ and $\mathrm{N}: \mathrm{P}$ ratios may also be relevant to producer-consumer interactions with effects on consumer driven C:N:P regeneration and plankton nutrient limitation (Sterner and Hessen 1994).

One unexpected result of our study was that DOC quality (as indicated by SUVA) was positively correlated with allochthonous FA but negatively with BAFA concentration in seston (Table 5). Other studies from boreal lakes showed increased bacterial abundance with increased colored terrestrial C content (Hessen 1985; Tranvik et al. 1988). Our study suggests the opposite, i.e., not supporting prediction 5. We found decreased seston $\omega 3: \omega 6$ and BAFA with increasing SUVA and decreased seston $\omega 3: \omega 6$ and BAFA in lakes from Jämtland compared to Abisko (Figs. 5; S2a,b). Jämtland lakes had a higher humic fraction in DOC with higher FA of terrestrial origin [i.e., LongSAFA and MUFA particularly oleic acid, the latter is generally abundant in terrestrial plants (cf. Napolitano 1999)] and higher abundance of recalcitrant terrestrial organic matter in seston than in Abisko lakes (Fig. 5). These differences could be related to climate [i.e., the warmer and wetter climate promotes higher catchment loadings of recalcitrant DOC to Jämtland compared to Abisko lakes (Laudon et al. 2012)] and vegetation [i.e., the greater extent of vegetation cover in the catchments of Jämtland lakes (almost 100\% covered by deciduous forest) compared to Abisko lakes ( $<50 \%$ covered by deciduous forest)] (Table 1). Further, autochthonous organic matter may be a more preferable substrate for bacterial growth than the allochthonous counterpart (Brett et al. 2017). The autochthonous organic matter, which may originate from benthic primary production (Rodríguez et al. 2013) that can dominate over pelagic primary production in the Abisko clear-water lakes (Ask et al. 2009), has been shown to be channeled via pelagic bacterioplankton to zooplankton (Karlsson and Säwström 2009). Hence, the higher abundances of bacteria-specific FA in seston in Abisko could therefore be an important complementary food resource for retrieving $\mathrm{C}$ and $\mathrm{P}$, in addition to that of phytoplankton, especially for non-selective filtering feeding zooplankton such as Daphnia (Wenzel et al. 2012).

Overall, our findings show that differences in $\mathrm{N}$ deposition and lake water N:P stoichiometry not only influence nutrient limitation of phytoplankton but also quantity and quality of phytoplankton in Swedish mountain lakes. Our findings further illustrate that the nutritional quality of the food resources, in terms of $\omega 3: \omega 6$ FA ratio and bacterial $\mathrm{FA}$ in seston, is influenced by the relative proportions of autochthonous versus allochthonous DOC sources (i.e., DOC aromaticity). In northern lakes where global changes are resulting in changes in lake water N:P stoichiometry induced from declining $\mathrm{N}$ deposition (Isles et al. 2018), and in changes in light regime induced from increased terrestrial loadings of colored DOC (Creed et al. 2018), the quality of basal resources are likely to be altered towards reduced EPA and BAFA content and enhanced mineral $\mathrm{P}$ content in 
seston. These effects may subsequently manifest differently up the pelagic food chain depending on whether zooplankton are constrained by resource stoichiometry or fatty acid composition.

Acknowledgements Open access funding provided by Umea University. We thank Petter Johansson for field and laboratory assistance. This study was supported by grants from the Swedish Research Council (VR) (d.nr. 621-2014-5909) and the Knut and Alice Wallenberg Foundation (d.nr. 2016.0083). We also acknowledge our support for our labs from the Chemical Biological Centre (KBC-group) at UmU.

Open Access This article is licensed under a Creative Commons Attribution 4.0 International License, which permits use, sharing, adaptation, distribution and reproduction in any medium or format, as long as you give appropriate credit to the original author(s) and the source, provide a link to the Creative Commons licence, and indicate if changes were made. The images or other third party material in this article are included in the article's Creative Commons licence, unless indicated otherwise in a credit line to the material. If material is not included in the article's Creative Commons licence and your intended use is not permitted by statutory regulation or exceeds the permitted use, you will need to obtain permission directly from the copyright holder. To view a copy of this licence, visit http://creativecommons.org/licenses/by/4.0/.

\section{References}

Ahlgren G (1983) Comparison of methods for estimation of phytoplankton carbon. Arch Hydrobiol 98:489-508

Ahlgren G, Hyenstrand P (2003) Nitrogen limitation effects of different nitrogen sources on nutritional quality of two freshwater organisms, Scenedesmus quadricauda (Chlorophyceae) and Synechococcus sp. (Cyanophyceae). J Phycol 39:906-917

Andersen T (1997) Herbivores as sources and sinks for nutrients. Ecological Series 129. Springer, New York

Ask J, Karlsson J, Persson L, Ask P, Byström P, Jansson M (2009) Terrestrial organic matter and light penetration effects on bacterial and primary production in lakes. Limnol Oceanogr 54:2034-2040

Bergström A-K (2010) The use of TN: TP and DIN: TP ratios as indicators for phytoplankton nutrient limitation in oligotrophic lakes affected by $\mathrm{N}$ deposition. Aquat Sci 72:277-281

Bergström A-K, Jansson M (2006) Atmospheric nitrogen deposition has caused nitrogen enrichment and eutrophication of lakes in the northern hemisphere. Glob Change Biol 12:635-643

Bergström A-K, Blomqvist P, Jansson M (2005) Effects of atmospheric nitrogen deposition on nutreint limitation and phytoplankton biomass in unproductive Swedish Lakes. Limnol Oceanogr 50:987-994

Bergström A-K, Jonsson A, Jansson M (2008) Phytoplankton response to nitrogen and phosphorus along a gradient in atmospheric nitrogen deposition. Aquat Biol 4:55-64

Bergström A-K, Faithfull CL, Karlsson D, Karlsson J (2013) Nitrogen deposition and warming-effects on phytoplankton nutrient limitation in subarctic lakes. Glob Change Biol 19:2557-2568

Bergström A-K, Karlsson D, Karlsson J, Vrede T (2015) N-limited consumer groth and low nutrient regeneration $\mathrm{N}: \mathrm{P}$ ratios in lakes with low N deposition. Ecosphere 61(1):2557-2568 (Article 9)

Bergström AK, Karlsson J (2019) Light and nutrient control phytoplankton biomass responses to global change in northern lakes. Glob Change Biol 25:2021-2029
Brett MT, Bunn SE, Chandra S et al (2017) How important are terrestrial organic carbon inputs for secondary production in freshwater ecosystems? Freshw Biol 62:833-853

Canham CD, Pace ML, Weathers KC, McNeil EW, Bedford BL, Murphy L, Quinn S (2012) Nitrogen deposition and lake nitrogen concentrations: a regional analysis of terrestrial controls and aquatic linkages. Ecosphere 3(7): art66

Carpenter SR, Cole JJ, Kitchell JF, Pace ML (1998) Impact of dissolved organic carbon, phosphorus, and grazing on phytoplankton biomass and production in lakes. Limnol Oceanogr 43:73-80

Chapin FS III, Petersort G, Berkes F et al (2004) Resilience and vulnerability of Northern regions to social and environmental change. AMBIO J Hum Environ 33:344-349

Creed IF, Bergström A-K, Trick CG et al (2018) Global change-driven effects on dissolved organic matter composition: implications for food webs of northern lakes. Glob Change Biol 24:3692-3714

de Wit HA, Valinia S, Weyhenmeyer GA et al (2016) Current browning of surface waters will be further promoted by wetter climate. Environ Sci Technol Lett 3:430-435

Deininger A, Faithfull CL, Bergström A-K (2017) Phytoplankton response to whole lake inorganic $\mathrm{N}$ fertilization along a gradient in dissolved organic carbon. Ecology 98:982-994

Eimers MC, Watmough SA, Paterson AM, Dillon PJ, Yao H (2009) Long-term declines in phosphorus export from forested catchments in south-central Ontario. Can J Fish Aquat Sci 66:1682-1692

Elser JJ, Andersen T, Baron JS et al (2009a) Shifts in lake N:P stoichiometry and nutrient limitation driven by atmospheric nitrogen deposition. Science 326:835-837

Elser JJ, Kyle M, Steger L, Nydick KR, Baron JS (2009b) Nutrient availability and phytoplankton nutrient limitation across a gradient of atmospheric nitrogen deposition. Ecology 90:3062-3073

Elser JJ, Peace AL, Kyle M et al (2010) Atmospheric nitrogen deposition is associated with elevated phosphorus limitation of lake zooplankton. Ecol Lett 13:1256-1261

Finstad AG, Andersen T, Larsen S, Tominaga K, Blumentrath S, de Wit HA, Hessen DO (2006) From greening to browning: catchment vegetation development and reduced S-deposition promote organic carbon load on decadal time scale in Nordic lakes. Sci Rep 6:1-8

Grieve A, Lau DCP (2018) Do autochthonous resources enhance trophic transfer of allochthonous organic matter to aquatic consumers, or vice versa? Ecosphere 9(6): 02307

Gulati RD, DeMott WR (1997) The role of food quality for zooplankton: remarks on the state-of-the-art, perspectives and priorities. Freshw Biol 38:753-768

Gutseit K, Berglund O, Granéli W (2007) Food quality for Daphnia in humic and clear water lakes. Freshw Biol 52:344-356

Hessen DO (1985) The relationship between bacterial carbon and dissolved humic compounds in oligotrophic lakes. FEMS Microbiol Ecol 31:215-223

Hessen DO (2013) Inorganic nitrogen deposition and its impacts on $\mathrm{N}: \mathrm{P}$ ratios and lake productivity. Water 5:327-341

Hessen DO, Lyche A (1991) Interspecific and intraspecific variations in zooplankton elemental composition. Arch Hydrobiol 121:343-353

Hessen DO, Andersen T, Brettum P, Faafeng BA (2003) Phytoplankton contribution to sestonic mass and elemental ratio in lakes: implications for zooplankton nutrition. Limnol Oceanogr 48:1289-1296

Holmgren S (1983) Phytoplankton biomass and algal composition in natural, fertilized and polluted subarctic lakes. Acta Univ Ups 674:16 (Uppsala University, 476 Uppsala)

Huser BJ, Futter MN, Wang R, Fölster J (2018) Persistent and widespread long-term phosphorus declines in Boreal lakes in Sweden. Sci Total Environ 613-614:240-249 
Isles PDF, Creed IF, Bergström A-K (2018) Recent synchronous declines in DIN:TP in Swedish lakes. Glob Biogeochem Cycles 32:208-225

Jansson M, Bergström A-K, Drakare S, Blomqvist P (2001) Nutrient limitation of bacteriooplankton and phytoplankton in humic lakes in northern Seden. Freshw Biol 46:653-666

Jansson M, Karlsson J, Blomqvist P (2003) Allochthonous organic carbondecreaseses pelagic energy mobilization in lakes. Limnol Oceanogr 48:1711-1716

Jansson M, Bergström A-K, Lymer D, Vrede K, Karlsson J (2006) Bacterioplankton growth and nutrient use efficiencies under variable organic carbon and inorganic phosphorus ratios. Microb Ecol $52: 358-364$

Jansson M, Jonsson A, Andersson A, Karlsson J (2010) Biomass and structure of plantonic communities along an air temperature gradient in subarctic Sweden. Freshw Biol 55:691-700

Jones RI (1992) The influence of humic substances on lacustrine planktonic food webs. Hydrobiologia 229:73-91

Karlsson J, Säqström C (2009) Benthic algae support zooplankton growth during winter in a clear-water lake. Oikos 118:539-544

Kelly PT, Solomon CT, Zwart JA, Jones SE (2018) A framework for understanding variation in pelagic gross primary production of lake ecosystems. Ecosystems 21:1364-1376

Kibby HV (1971) Energetics and population dynamics of Diaptomus gracilis. Ecol Monogr 41:311-327

Kortelainen P, Mattsson T, Finér L, Ahtiainen M, Saukkonen S, Sallantaus T (2006) Controls on the export of C, N, P and Fe from undisturbed boreal catchments, Finland. Aquat Sci Res Across Bound 68(4):453-468

Kritzberg ES (2017) Centennial-long trends of lake browning show major effect of afforestation. Limnol Oceanogr Lett 2:105-112

Lampert W (1977) Studies on the carbon balance in Daphnia pulex de Geer as related to environmental conditions. 4. Determination of the "threshold" concentration as a factor controlling the abundance of zooplankton species. Arch Hydrobiol Suppl 48:361-368

Lau DCP, Sundh I, Vrede T, Pickova J, Goedkoop W (2014) Autochthonous resources are the main driver of consumer production in dystrophic boreal lakes. Ecology 95:1506-1519

Lau DCP, Vrede T, Pickova J, Goedkoop W (2012) Fatty acid composition of consumers in boreal lakes—variation across species, space and time. Freshw Biol 57:24-38

Lau DCP, Goedkoop W, Vrede T (2013) Cross ecosystem differences in lipid composition and growth limitation of a benthic generalist consumer. Limnol Oceanogr 58:1149-1164

Laudon H, Buttle J, Carey SK et al (2012) Cross-regional prediction of long-term trajectory of stream water DOC response to climate change. Geophys Res Lett 39:L18404

Lindsay JB (2016) Whitebox GAT: a case study in geomorphometric analysis. Comput Geosci 95:75-84

Monteith DT, Stoddard JL, Evans CD et al (2007) Dissolved organic carbon trends resulting from changes in atmospheric deposition chemistry. Nature 450:537-540

Müller-Navarra DC (1995) Biochemical versus mineral limitation in Daphnia. Limnol Oceanogr 40(7):1209-1214

Müller-Navarra DC (2008) Food web paradigms: the biochemical view on trophic interactions. Int Rev Hydrobiol 93(4-5):489-505

Müller-Navarra DC, Brett MT, Liston AM, Goldman CR (2000) A highly unsaturated fatty acid predicts carbon transfer between primary producers and consumers. Nature 403:74-77
Napolitano GE (1999) Fatty acids as trophic and chemical markers in freshwater ecosystems. In: Arts MT, Wainman BC (eds) Lipids in freshwater ecosystems. Springer, New York, pp 21-44

Persson J, Brett MT, Vrede T, Ravet JL (2007) Food quantity and quality regulation of trophic transfer between primary producers and a keystone grazer (Daphnia) in pelagic freshwater food webs. Oikos 116:1152-1163

Rodríguez P, Ask J, Hein CL, JanssonM KJ (2013) Benthic organic carbon release stimulates bacterioplankton production in a clearwater subarctic lake. Freshw Sci 32(1):176-182

Simpson D, Andersson C, Christensen JH et al (2014) Impacts of climate and emission changes on nitrogen deposition in Europe: a multi-model study. Atmos Chem Phys 14(13):6995-7017

Sterner RW (1997) Modeling interactions of food quality and quantity in homeostatic consumers. Freshw Biol 38:473-481

Sterner RW, Elser JJ (2002) Ecological stoichiometry. Princeton University Press, Princeton

Sterner RW, Hessen DO (1994) Algal nutrient limitation and the nutrition of aquatic herbivores. Annu Rev Ecol Syst 25:1-29

Sterner RW, Elser JJ, Fee EJ, Guildford SJ, Chrzanowski TH (1997) The light:nutrient ratio in lakes: the balance of energy and materials affects ecosystem structure and process. Am Nat 150:663-684

Sundbom M, Vrede T (1997) Effects of fatty acids and phosphorus content of food on the growth, survival and reproduction of Daphnia. Freshw Biol 38:665-674

Taipale S, Strandberg U, Peltomaa E, Galloway AWE, Ojala A, Brett MT (2013) Fatty acid composition as biomarkers of freshwater microalgae: analysis of 37 strains of microalgae in 22 genera and in seven classes. Aquat Microb Ecol 71(2):165-178

Taipale S, Sami J, Kainz MJ, Brett MT (2015) A low $\omega-3: \omega-6$ ratio in Daphnia indicates terrestrial resource utilization and poor nutritional condition. J Plankton Res 37(3):596-610

Tranvik LJ (1988) Availability of dissolved organic carbon for planktonic bacteria in oligotrophic lakes of differing humic content. Microb Ecol 16:311-322

Vrede T, Tranvik LJ (2006) Iron constraints on planktonic primary production in oligotrophic lakes. Ecosystems 9:1094-1105

Weishaar JL, Aiken GR, Bergamaschi BA et al (2003) Evaluation of specific ultraviolet absorbance as an indicator as an indicator of the chemical composition and reactivity of dissolved organic carbon. Environ Sci Technol 37:4702-4708

Wenzel A, Bergström A-K, Jansson M, Vrede T (2012) Survival, growth and reproduction of Daphnia galeata feeding on single and mixed Pseudomonas and Rhodomonas diets. Freshw Biol $57: 835-846$

Williamson CE, Dodds W, Kratz TK, Palmer MA (2008) Lakes and streams as sentinels of environmental change in terrestrial and atmospheric processes. Front Ecol Environ 6:247-254

Williamson CE, Overholt EP, Brentrup JA et al (2016) Sentinel responses to droughts, wildfires, and floods: effects of UV radiation on lakes and their ecosystem services. Front Ecol Environ 14:102-109

Publisher's Note Springer Nature remains neutral with regard to jurisdictional claims in published maps and institutional affiliations. 